1998

\title{
Halacha and Aggada: Translating Robert Cover's Nomos and Narrative
}

Samuel J. Levine

slevine@tourolaw.edu

Follow this and additional works at: https://digitalcommons.tourolaw.edu/scholarlyworks

Part of the Other Law Commons

\section{Recommended Citation}

1998 Utah L. Rev. 465 (1998)

This Article is brought to you for free and open access by the Faculty Scholarship at Digital Commons @ Touro Law Center. It has been accepted for inclusion in Scholarly Works by an authorized administrator of Digital Commons @ Touro Law Center. For more information, please contact Iross@tourolaw.edu. 


\section{Halacha and Aggada: Translating Robert Cover's Nomos and Narrative \\ Samuel J. Levine*}

TABLE OF CONTENTS

Page

I. INTRODUCTION $\ldots \ldots \ldots \ldots \ldots \ldots \ldots \ldots \ldots \ldots \ldots$

II. WHAT ARE "NOMOS" AND "NARRATIVE"? . . . . . . . . . . . 469

A. Cover's Analysis of American Legal Narrative . . . . . . 469

B. Cover's Analysis of Biblical Narrative ......... 475

III. NomoS AND NARRATIVE IN JEWISH LEgAL SOURCES . . . . . 485

A. Halacha and Aggada in the Torah . . . . . . . . . 485

B. Halacha and Aggada in the Talmud ............ 492

C. Halacha and Aggada in Maimonides' Code of Law . . . 496

IV. ROBERT COVER AND HAYIM NAHMAN BIALIK: TwO SIDES OF A SINGLE SHIELd . . . . . . . . . . . . . . . 499

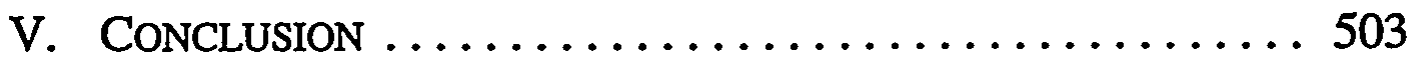

\section{INTRODUCTION}

In his groundbreaking 1983 article, Nomos and Narrative, ${ }^{1}$ Robert Cover began to develop the themes that would dominate his writings for the rest of

'Assistant Legal Writing Professor \& Lecturer in Jewish Law, St. John's University School of Law; LL.M. 1996, Columbia University; Ordination 1996, Yeshiva University; J.D. 1994, Fordham University; B.A. 1990, Yeshiva University.

I thank Barbara Black, Jim Elkins, Jim Fleming, Martin Golding, Kent Greenawalt, Bernard Jackson, Rabbi Joseph Lukinsky, Geoffrey Miller, James Perkins, Irene Rosenberg, Jeff Roth, Tom Shaffer, Avi Soifer, Carol Weisbrod, and Stephen Wizner for helpful comments and conversations and general encouragement.

'Robert M. Cover, The Supreme Court, 1982 Term-Foreword: Nomos and Narrative, 97 HARV. L. REV. 4 (1983) [hereinafter Cover, Nomos and Narrative]. 
his life. Two of these themes, in particular, also would exert a profound influence on legal scholarship, and illustrate the significance of Cover's ideas to issues affecting the broader academy as well. ${ }^{2}$

One of the striking elements of Nomos and Narrative is its heavy reliance on Jewish sources as a basis for analyzing contemporary American legal theory. ${ }^{3}$ Many scholars have commented on Cover's use of Jewish sources, ${ }^{4}$ including some scholars who have offered careful critiques of Cover's application of Jewish sources to support his view of law. ${ }^{5}$

Another theme which Cover began to develop in Nomos and Narrative, as indicated in the title of the article, was the use of "narrative" in legal theory. ${ }^{6}$ For Cover, the basis of this theme was the thesis that "[n]o set of

${ }^{2}$ The breadth of Cover's influence on the academy is apparent in the diversity of journals which have published tribute volumes to him, including 8 CARDOZO STUDIES IN LAW AND LITERATURE 1 (1996); 45 CONSERVATIVE JUDAISM 1 (1993); 7 J.L. \& RELIGION 1 (1989); 96 YALE L.J. 1699 (1987). Other tributes to Cover can be found in NARRATIVE, VIOLENCE, AND THE LAW: THE ESSAYS OF ROBERT COVER (Martha Minow et al. eds., 1993).

${ }^{3}$ Cover continued his reliance on Jewish sources in his legal scholarship in Robert $M$. Cover, Bringing the Messiah Through Law: A Case Study, in Nomos XXX: RELIGION, MORALITY AND THE LAW 201 (J. Roland Pennock \& John W. Chapman eds., 1988); Robert M. Cover, Obligation: A Jewish Jurisprudence of the Social Order, 5 J.L. \& RELIGION 65 (1987); Robert M. Cover, The Folktales of Justice: Tales of Jurisdiction, 14 CAP. U. L. REV. 179 (1985).

${ }^{4}$ See, e.g., Bernard J. Hibbits, Making Sense of Metaphors: Visuality, Aurality, and the Reconfiguration of American Legal Discourse, 16 CARDOZO L. REV. 229, 339 (1994) (describing Cover as "the prime mover in the reintroduction of Jewish values to contemporary American legal discourse"); Suzanne Last Stone, In Pursuit of the Counter-Text: The Turn to the Jewish Legal Model in Contemporary American Legal Theory, 106 HARV. L. REV. 813, 820 (1993) (stating that in law, "Robert Cover made it respectable to draw on the Jewish tradition in public discourse"); Steven L. Winter, The Cognitive Dimension of the Agon Between Legal Power and Narrative Meaning, 87 MiCH. L. REV. 2225 n.3 (1989) (acknowledging "the liberating effect" of Cover's work on the author's "sense of my own past," showing how the "intellectual abundance of [Jewish sources] can be a profound source of analytic insight").

For discussions of the effect of Cover's Jewish identity on his intellectual commitments, see Joseph Lukinsky \& Robert Abramson, Robert Cover, A Jewish Life, 45 CONSERVATIVE JUDAISM 4 (1993); Joseph Lukinsky, Law in Education: A Reminiscence with Some Footnotes to Robert Cover's Nomos and Narrative, 96 Y ALE L.J. 1836 (1987); Gordon Tucker, The Sayings of the Wise Are Like Goads: An Appreciation of the Works of Robert Cover, 45 CONSERVATIVE JUDAISM 17 (1993); Stephen Wizner, Tributes to Robert M. Cover, 96 YALE L.J. 1707 (1987); Nomi M. Stolzenberg, Un-covering the Tradition of Jewish Dissimilation: Frankfurter, Bickel, and Cover on Judicial Review, 3 S. CAL. INTERDISC. L.J. 809 (1994).

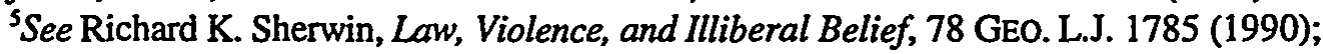
Stone, supra note 4.

${ }^{6}$ Cover continued to explore narrative and its relationship to law in Cover, Bringing the Messiah Through Law: A Case Study, supra note 3; Robert M. Cover, The Bonds of Constitutional Interpretation: Of the Word, the Deed, and the Role, 20 GA. L. REV. 815 (1986); Cover, The Folktales of Justice: Tales of Jurisdiction, supra note 3; Robert M. Cover, Violence and the Word, 95 YALE L.J. 1601 (1986). 
legal institutions or prescriptions exists apart from the narratives that locate it and give it meaning," and "[o]nce understood in the context of the narratives that give it meaning, law becomes not merely a system of rules to be observed, but a world in which we live." Cover's explanation of these ideas coincided with and influenced the emergence of what has become known as "legal storytelling."

${ }^{7}$ Cover, Nomos and Narrative, supra note 1, at 4-5.

${ }^{8}$ The list of scholarship relating to legal storytelling, often referred to as legal "narrative," is a long and varied one, including, for example, DERRICK BEL, AND WE ARE NOT SAVED: THE ELUSIVE QUEST FOR RACIAL JUSTICE (1987); RICHARD DELGADO, THE RODRIGO CHRONICLES (1995); LAW'S STORIES: NARRATIVE AND RHETORIC IN THE LAW (Peter Brooks \& Paul Gewirtz eds., 1996); RICHARD WEISBERG, POETHICS AND OTHER STRATEGIES OF LAW AND LITERATURE (1992); ROBIN WEST, NARRATIVE, AUTHORITY, AND LAW (1993); PATRICIA J. WILLIAMS, THE ALCHEMY OFRACE AND RIGHTS (1991); Kathryn Abrams, Hearing the Call of Stories, 79 CAL. L. REV. 971 (1991); Benjamin L. Apt, Aggada, Legal Narrative, and the Law, 73 OR. L. REV. 943 (1994); Jane B. Baron \& Julia Epstein, Is Narrative Law?, 45 BuFf. L. REv. 141 (1997); Jane B. Baron, Resistance to Stories, 67 S. CAL. L. REv. 255 (1994); Jane B. Baron, Intention, Interpretation, and Stories, 42 DUKE L.J. 630 (1992); Jane B. Baron, The Many Promises of Storytelling in Law, 23 RUTGERS L. REV. 79 (1991); Colloquium on Legal Scholarship, 13 Nova L. REV. 1 (1988); Mary I. Coombs, Outsider Scholarship: The Law Review Stories, 63 U. COLO. L. REV. 683 (1992); Mary I. Coombs, Telling the Victim's Story, 2 TEX. J. WOMEN \& LAW 277 (1993); Anne M. Coughlin, Regulating the Self: Autobiographical Performances in Outsider Scholarship, 81 VA. L. REV. 1229 (1995); Cover, Nomos and Narrative, supra note 1; Cover, The Folktales of Justice: Tales of Jurisdiction, supra note 3; Richard Delgado \& Jean Stefancic, Norms and Narratives: Can Judges Avoid Serious Moral Error?, 69 TEX. L. REV. 1929 (1991); William N. Eskridge, Jr., Gaylegal Narratives, 46 STAN. L. REV. 607 (1994); Feminist Jurisprudence Symposium, 24 GA. L. REV. 761 (1990); Lynne N. Henderson, Legality and Empathy, 85 MiCH. L. REV. 1574 (1987); Hibbits, supra note 4; Alex M. Johnson, Jr., The New Voice of Color, 100 YALE L.J. 2007 (1991); Charles R. Lawrence III, The Word and the River: Pedagogy as Scholarship as Struggle, 65 S. CAL. L. REv. 2231 (1992); Mari J. Matsuda, Looking to the Bottom: Critical Legal Studies and Reparations, 22 HARV. C.R.-C.L. L. REV. 323 (1987); Pedagogy of Narrative: A Symposium, 40 J. LEGAL EDUC. 1 (1990); Edward B. Rock, Saints and Sinners: How Does Delaware Corporate Law Work?, 44 UCLAL. REV. 1009 (1997); Vicki Schultz, Telling Stories About Women and Work: Judicial Interpretations of Sex Segregation in the Workplace in Title VII Cases Raising the Lack of Interest Argument, 103 HARV. L. REV. 1749 (1990); Norman Silber \& Geoffrey Miller, Toward "Neutral Principles" in the Law: Selections from the Oral History of Herbert Wechsler, 93 COLUM. L. REV. 854 (1993); Symposium, Legal Storytelling, 87 MiCH. L. REv. 2073 (1989); Symposium on Reproductive Rights, 13 Nova L. REv. 329 (1989); Symposium, The Voices of Women, 77 IOWA L. REv. 5 (1991); Symposium, Excluded Voices: Realities in Law and Law Reform, 42 U. MLAMI L. REV. 1 (1987); Mark Tushnet, The Degradation of Constitutional Discourse, 81 GEO. L.J. 251 (1992); Patricia J. Williams, Commercial Rights and Constitutional Wrongs, 49 MD. L. REV. 293 (1990); Patricia Williams, Reordering Western Civilization, 43 STAN. L. REV. 1327 (1991); Winter, supra note 4.

These and other works are listed, in different combinations, in numerous law review articles. As suggested by the dates of these works, Nomos and Narrative is consistently one of the oldest works cited, and is often acknowledged, explicitly or implicitly, as one of the seminal works in this area of legal scholarship. See also R. Richard Banks, The Political Economy of 
In this Article, I examine the interrelationship in Nomos and Narrative between these two themes-the reliance on Jewish sources and the presentation of the concept of "narrative" in law. I suggest that a proper understanding of Cover's use of the two themes requires that they be viewed as interdependent components of his thinking. Specifically, I look to examine Cover's concept of "narrative" in the law through an examination of how he viewed the parallel concept of aggada in Jewish law. Through this study, I aim to show that, although Cover found that "narrative" may find expression, at times, in the literary form of storytelling, his concept of "legal narrative" is a broader one, encompassing the wider societal context in which law functions, and one which may best be understood in light of the complex interplay between halacha and aggada in Jewish law. ${ }^{9}$

Toward the goal of understanding Cover's conception of narrative, Part II of this Article takes a close look at Cover's definition and descriptions of narrative. Though recognizing that Cover examines the relationship between nomos and narrative in a number of contexts, this Part suggests that focusing on his analysis of the relationship of halacha and aggada in Jewish law is particularly helpful in shedding light on his understanding of nomos and narrative in other contexts as well. In an attempt to flesh out Cover's concept of halacha and aggada, Part III discusses the rich tradition and significance of the interplay between halacha and aggada in some of the major sources of Jewish law, including the Torah, the Talmud, and Maimonides' Code of Law.

Racial Discourse, 9 YALE J.L. \& HUMAN. 217, 218 (1997) (citing Nomos and Narrative as evidence of the fact that "the use of narrative in legal scholarship is not a recent development"); Daniel A. Farber \& Suzanna Sherry, Telling Stories Out of School: An Essay on Legal Narratives, 45 STAN. L. REV. 807, 807 (1993) (stating that "the law and literature movement taught us that stories have much to say to lawyers, and Robert Cover taught us that law is itself a story"); Paul Schiff Berman, Note, Rats, Pigs, and Statues on Trial: The Creation of Cultural Narratives in the Prosecution of Animals and Inanimate Objects, 69 N.Y.U. L. REV. 288, 291 n.21 (1994) (stating that "[o]ver the past several decades, anthropologists, literary critics, and legal scholars have increasingly studied the role of narratives in structuring our experience of the world," and listing Cover as representative of category of legal scholars).

'In Cover's framework, halacha parallels nomos, while aggada parallels narrative. See infra notes 93-102 and accompanying text.

Because the words "halacha" and "aggada" are transliterations of Hebrew, they appear in English works in a variety of forms. Halacha is sometimes written as halachah, halakha, or halakhah, while aggada is sometimes written as aggadah. In addition, both words are occasionally capitalized even when used in the middle of a sentence, and they are not always italicized in English works.

In the interest of consistency, I have altered the spelling in some quotations to conform with a uniform transliteration of "halacha" and "aggada," and their adjective forms, "halachic" and "aggadic." In the interest of faithfulness to the original works, however, I have not altered the spellings of the titles of the works cited.

In addition, all translations of Hebrew sources are my own, unless otherwise noted. 
Finally, building on the ideas developed in Parts II and II, Part IV compares Cover's thoughts on the nature of and relationship between nomos and narrative to parallel observations of Hayim Nahman Bialik, an important Jewish modern literary figure, regarding halacha and aggada. The Article concludes with the observation, based in part on the comments of some of Cover's friends, that his emphasis on integrating the study of nomos and narrative together with halacha and aggada seemed to reflect a similarly integrated world view and way of life.

\section{WHAT ARE "NOMOS" AND "NARRATIVE"?}

\section{A. Cover's Analysis of American Legal Narrative}

In contemporary legal scholarship, the term "narrative" is often equated with legal "storytelling." An early example of this equation is found in the opening of Professor Kim Scheppele's foreword to the influential 1989 Michigan Law Review Symposium, Legal Storytelling: "Why is there such a rush to storytelling? Why has narrative become such an important and recurring theme in legal scholarship these days?"10 In a footnote documenting this emergence of "storytelling" or "narrative" in legal scholarship, Professor Scheppele cites numerous books and law review articles relating to the "lawand-literature movement, in which the legal narrative theme sounds prominently." "Professor Scheppele includes Robert Cover among the "founders" of this "movement," and she cites a number of his works, the earliest of which is Nomos and Narrative. ${ }^{12}$

Indeed, in Nomos and Narrative, Cover does look to "literature"-particularly biblical literature - as a means toward understanding law. In addition, as indicated by his careful attention to and respect for societal narratives, Cover recognizes the value of storytelling in legal analysis. Nevertheless, as Cover himself observed, certain terms, such as "Torah," "nomos," and "the Law," are "amenable to a range of meanings that serve both to enrich the term and to obscure analysis of it."13 The same can be said of the term "narrative." The aim of this Part is to identify the meanings which Cover intended for "narrative," by focusing on the definitions he supplied for this term, and his view of its relationship to what he called a "nomos." An analysis of Cover's use of the term "narrative" suggests

${ }^{10}$ Kim Lane Scheppele, Foreword: Telling Stories, 87 MiCH. L. REv. 2073, 2073 (1989).

"Id. at 2073 n.1.

${ }^{12} I d$.

${ }^{13}$ Cover, Nomos and Narrative, supra note 1 , at $11 \mathrm{n} .31$. 
that Cover was developing an idea broader than, though not inconsistent with, legal storytelling.

Cover introduces his piece by mapping a connection between "nomos" and "narrative." According to Cover, a nomos is a "normative universe," a "world of right and wrong, of lawful and unlawful."14 Although "formal institutions of the law, and the conventions of a social order are, indeed, important to that world," Cover is careful to emphasize that they are "but a small part of the normative universe."15 Rather, legal institutions and prescriptions must be "understood in the context of the narratives that give [them] meaning," narratives which complement legal precepts to create a nomos, "a world in which we live."16

Elaborating on the structure of this world, Cover emphasizes the important place of a "legal tradition" within a "complex normative world."17 Thus, a nomos includes "not only a corpus juris, but also a language and a mythos-narratives in which the corpus juris is located." 18 It is these narratives, or myths, that give meaning to the corpus juris, so that the law is understood within the broader context of societal norms and actions, ranging from "ordinary legal doctrine at work in mundane affairs," to "utopian and messianic yearnings," to "apologies for power and privilege" and critiques of "the justificatory enterprises of law." 19

Cover is particularly interested in examining the phenomenon by which communities place legal precepts within their societal narratives. In fact, Cover entertains a "fantasy" in which individual communities inhabit a "somewhat distinct nomos," dependent on their narratives and precepts, through which they "create law" and "give meaning to law."20 Thus, he admires the attitudes of the Mennonite and Anabaptist communities to the Free Exercise Clause of the United States Constitution. ${ }^{21}$ In Cover's view, the Mennonites and the Old Order Amish, like other insular communities, inhabit a unique normative world, in which legal precepts such as the First Amendment have meaning only against the backdrop of the community's historical narrative. ${ }^{22}$

Cover further admires the means through which these communities communicated their concerns, indeed their own "understanding of the First

\footnotetext{
${ }^{14} I d$. at 4.

${ }^{15}$ Id.

${ }^{16} I d$. at 4-5.

${ }^{17} I d$. at 9.

${ }^{18} I d$.

${ }^{19} I d$.

${ }^{20} I d$. at 40.

${ }^{21}$ See id. at 27.

${ }^{22}$ See id. at 27-28.
} 
Amendment," which, Cover asserts, "within the domain of constitutional meaning . . . assumes a status equal (or superior) to that accorded to the understanding of the Justices of the Supreme Court." ${ }^{32} \mathrm{He}$ observes that the Mennonites' brief, submitted to the Court in Bob Jones University v. United States, ${ }^{24}$ appears "in the form of a simple narrative" which described the historical persecution the church endured, and thus explained the basis for the Mennonites' expansive view of the First Amendment's protections of religious liberty. ${ }^{25}$ Similarly, Cover notes, in Wisconsin v. Yoder, ${ }^{26}$ the Amish depicted, in their brief, a "common narrative" which placed the Amish approach toward First Amendment religious protections within the context of the broader nomos they inhabited, a nomos that incorporated a history of religious persecution. ${ }^{27}$

As Cover further examines the Mennonites' brief, he identifies narratives, including "the quasi-sacred tales of martyrs" and "the more recent stories of conscientious objectors," which "help to create the identity of the believer and to establish the central commitment from which [the] law ... of the state will be addressed."28 Thus, Cover acknowledges the value of stories as an instrument for conveying the attitudes underlying a community's normative world. Such an expression of a community's narrative can help judges and others outside the community appreciate, and consider the viability of, the community's understanding of the law of the state, as seen through the lens of the community's unique nomos.

Nevertheless, when Cover conceives of "narrative," he appears to refer to a concept broader than literary creations that take the form of specific stories or myths, reflecting a community's perspectives on legal precepts and their place within a wider normative world. Cover uses "narrative" to refer to the community's actual societal norms, attitudes, and aspirations, which "bespeak the range of the group's commitments" and "provide resources for justification, condemnation, and argument by actors within the group, who must struggle to live their law." ${ }^{\text {"29 }}$ Indeed, according to Cover, basic to the

${ }^{23} I d$. at 28.

${ }^{24} 461$ U.S. 574 (1983).

${ }^{25}$ Cover, Nomos and Narrative, supra note 1, at 26.

${ }^{26} 406$ U.S. 205 (1972).

${ }^{27}$ Cover, Nomos and Narrative, supra note 1, at 26.

${ }^{28} I d$. at 28. See, e.g., C. ARNOLD SNYDER, THE LIFE AND THOUGHT OF MICHAEL SATTLER 89-107 (1984) (tracing life of Swiss Anabaptist martyr and noting that throughout history, many would follow his example).

${ }^{29}$ Cover, Nomos and Narrative, supra note 1, at 46. Thus, the word "narrative," in Cover's system, can have more than one meaning, depending on its context. At times, "narrative" denotes the literary device of storytelling. When used in connection and contrast with the concept of a nomos, however, the word "narrative" takes on its broader meaning described 
"[c]reation of legal meaning" is "a commitment to projecting the understanding of the norm .... [i]nto the teleological vision that the interpretation

above.

The two meanings of "narrative" in this system may parallel the distinct but complementary concepts of a "metaphor" and its accompanying "images." See James R. Elkins, The Stories We Tell Ourselves in Law, 40 J. LEGAL EDUC. 47, 48 (1990). Professor Elkins writes of his own "various notions about how life works and what it means to be a lawyer and law teacher." Id. at 47 . He refers to these "notions" as "metaphors, accompanied, as metaphors inevitably are, by images: the lawyer as hired-gun, the lawyer as friend, the teacher as midwife, life as a journey, life as a story." Id. In Elkins' scheme, metaphors are literary devices that "orient us toward a story" and "connect with and energize the story that we are trying to tell .... They . . . fit a story I am living or a story that I hope to live or want to avoid living." Id. Extending his discussion to "images," Elkins describes finding "a metaphor (and an image of yourself) that can take hold of you. The images that accompany the metaphor work their way into your life and your story." Id. at 48. He adds that "[t]o live as I do with the metaphors and images .... is to adopt - consciously and willingly, quietly and unconsciously, or violently and against my will-a particular story. The particularity of the story that I find myself living and trying to articulate is a bundle of metaphors and images." Id.

Elkins' notion of a "metaphor" parallels the use of "narrative" as a specific literary device. Indeed, Elkins defines narrative as "a primary source of metaphors." Id. at $47 \mathrm{n}$.1. The broader notion of "images" is closer to Cover's use of "narrative" to describe the societal norms, goals, and commitments that contribute to a normative world that a community inhabits.

On a communal level, the dual usage of "narrative" in Cover's system may be mirrored in Professor Michael Perry's depiction of the distinct but related concepts of a "tradition" and a "foundational text" of a religious community, which he extends to a constitutional community. See MiCHAEL J. PERRY, MORALITY, POLITICS AND LAW: A BICENTENNIAL ESSAY 136-37 (1988). Perry defines a "tradition" broadly, as "a history or narrative in which the central motif is an aspiration to a particular form of life, to certain projects, goals, ideals." Id. at 137. He adds that "the central discourse, in the case of a living tradition, is an argument-in Alasdair MacIntyre's terms, 'an historically extended, socially embodied argument'—about how that form of life is to be cultivated and revised." Id. (quoting ALASDAIR MACINTYRE, AFTER VIRTUE 207 (1981)). Perry offers a more narrow definition of a "foundational text": "the text that, in the community and tradition in question, is seen to charter, to mandate, the form of life to which the community and tradition aspire, and thus the text that, for the community and tradition, symbolizes that mandate." Id.

Perry emphasizes the "writtenness" and "permanence" of the literary form of the text, which he contrasts with the living and more inclusive nature of a communal "tradition." Id. Perry's view of a tradition, which he in fact defines in part as a "narrative," parallels Cover's use of "narrative" to depict a combination of communal history, values, and aspirations.

This understanding of Cover's view of "narrative" is also, I think, consistent with that of Professor Steven Winter, who has suggested that

Cover's "narratives" are themselves best understood not as prototypical stories of specific historical events. Rather, if they are to operate meaningfully as law for the group, they must make the transition from specific historical narratives to stylized cultural constructs that operate as idealized cognitive models. In this view of his work, the phenomenon of polynomia that Cover describes is not a function of the subjective power of the various narrators, but rather a nondeterminate product of the imaginative cognitive constructions of different social experiences.

Winter, supra note 4, at 2270 . See infra note 90. 
implies." ${ }^{30}$ Therefore, Cover explains, the Amish interpret the legal principle of separation of church and state in the United States Constitution through the perspective of the Amish narrative, which places a supreme value on the community's maintaining its traditional insularity ${ }^{31}$ It is the commitment of the Amish community to its fundamental values-its "sacred narratives"32 - that gives legal meaning to the community's understanding of the First Amendment within its own nomos. ${ }^{33}$

The Mennonites and the Amish, in their respective briefs to the Supreme Court, used storytelling as an effective vehicle for expressing their communal narratives to those outside the community. While their approach may illustrate the usefulness and power of storytelling, such stories are not always available, and, even when produced by a community or by individuals within a community, may not sufficiently convey the richness of the societal attitudes that contribute to the creation of a nomos.

Indeed, without reference to specific instances of storytelling, Cover identifies a number of insular communities, each of which created its own unique nomos, together with the corresponding societal forces that set the boundaries in which the normative worlds functioned. For example, Cover cites Professor Carol Weisbrod's study of nineteenth-century utopian communities-in particular the Shaker community - in which "the voluntaristic character of the ideology of these communities ... dominated their constitutional thought."34 Thus, "the center of the Shaker nomos" was the strong communal narrative that emphasized "a vivid and literal social contract." "35 Likewise, Cover points to historical instances of "law creation," in which private actors used property and corporation law to assert control over societal norms. ${ }^{36}$ This phenomenon, which occurred in settings such as the "company town" of Pullman, Illinois, and the Massachusetts Bay Colony, ${ }^{37}$ illustrates the important role that a community's narrative can play, in not only giving meaning to a set of laws imposed on the community, but in actually creating a system of public law that grows out of that narrative. ${ }^{38}$

\footnotetext{
${ }^{30}$ Cover, Nomos and Narrative, supra note 1 , at 45 .

${ }^{31}$ See id.

${ }^{32}$ Id. at 29.

${ }^{33}$ See id. at 45 ,

${ }^{34}$ Id. at 30 (citing CAROL WeISBROD, THE BOUNDARIES OF UTOPIA 61-79 (1980)).

${ }^{35}$ Id. at 32.

${ }^{36} I d$. at $30-31$.

${ }^{37}$ See id.

${ }^{38}$ Cover cites Professor Barbara Black's description of "the processes by which a private law document came to have overpowering effect as the public law of the Massachusetts Bay Colony." Id. at 31 n.89 (citing Barbara Black, The Judicial Power and the General Court in Early Massachusetts (1634-1686) ch. 1 (1975) (unpublished Ph.D. dissertation, Yale
} 
As much as Cover admires and is fascinated by the capacity of insular communities to create and live within their own nomos, such an approach does not satisfy Cover's view of the transformative power of law. Cover describes law as a "bridge, linking a concept of a reality to an imagined alternative ... a connective between two states of affairs, both of which can be represented in their normative significance only through the devices of narrative." ${ }^{39}$ In this vein, borrowing heavily from his own study of judicial and societal attitudes toward slavery, ${ }^{40}$ Cover portrays a more ambitious use of communal or associative narrative, "redemptive constitutionalism." 41 In contrast to the Garrisonian abolitionists, who employed "nomian insularity" to withdraw from participation in a nomos that accepted slavery, the radical constitutionalists held "a vision of an alternative world in which the entire order of American slavery would be without foundation in law" requiring no less than "the transformation of the conditions of social life." Indeed, Cover celebrated the "radical constitutionalists" for asserting their anti-slavery construction of the Constitution against the opposing public nomos, thus seeking a redemptive end to slavery in the United States. ${ }^{43}$

In addition to presenting the notion of insular and redemptive models and their relationship to communal narratives, Cover's discussion of antislavery constitutionalism demonstrates a more subtle function of narrative in its relationship to legal precepts. As Cover notes earlier in the article, many actions have meaning only with regard to a norm. Indeed, the very same action can convey different symbolic messages, dependent on the actor's relationship to a set of rules governing the action. For example, Cover observes, the action of sleeping late on Sunday takes on a special significance when it expresses a refusal of the Sacraments; eating a snack on the tenth day of the Jewish month of Tishrei carries a unique meaning as a conscious desecration of the norm of fasting on Yom Kippur. ${ }^{44}$ Similarly, in relation to the institution of slavery and its accompanying norms, such as the fugitive slave acts, rescuing fugitives and assisting them and their rescuers was not only a practical act, but a symbolic one as well. ${ }^{45}$ In the context of a public

University Department of History)).

${ }^{39}$ Cover, Nomos and Narrative, supra note 1, at 9; infra text accompanying notes 177-78.

For discussions of the concept of law as a bridge, see generally Milner S. Ball, Law and Prophets, Bridges and Judges, 7 J.L. \& RELIGION 1, 1 (1989) Ronald R. Garet, Meaning and Ending, 96 YALE L.J. 1801, 1808-15 (1987).

${ }^{40}$ See ROBERT M. COVER, JUSTICE ACCUSED passim (1975).

${ }^{41}$ Cover, Nomos and Narrative, supra note 1, at 34.

${ }^{42} I d$. at 38-39.

${ }^{43} I d$.

${ }^{44}$ See id. at 8.

${ }^{45}$ See id. at 35. 
nomos that permitted slavery, the person who actively violated the fugitive slave acts did so as an expression of a constitutional philosophy, grounded in an abolitionist narrative at conflict with the legal institutions of the time.

Thus, Cover's analysis of the constitutionalism of antislavery provides, on a number of levels, an instructive illustration of his theories of the relationship between nomos and narrative. Yet, the most illuminating quality of Cover's focus on slavery may lie not as much in the substantive discussion of antislavery constitutionalism as in an important conceptual comparison he draws to biblical principles. Cover dedicates a significant and substantial portion of his Article to a discussion of the nomos and narrative of the biblical law of succession. ${ }^{46}$

Cover writes that "[i]n the Bible there is no earthly or heavenly precept so heavily loaded as that of Deuteronomy chapter 21 , verses 15 through 17 , because there is no precept rendered so problematic by the narratives in which the law is embedded." ${ }^{\text {47 }}$ In introducing his discussion of slavery, Cover poetically suggests that "[i]f there was a fault line in the normative topography of American constitutionalism-akin in significance and expressive power to the principle of succession in biblical life-it was, for four score and ten years, the place of slavery within the union." ${ }^{48}$ Similarly, he describes the "expressive potential" of certain rules of slavery, such as the fugitive slave acts, as "comparable to that of Deuteronomy 21:15-:17."49 These explicit comparisons, through which Cover apparently acknowledges a greater "expressive power" in the biblical passages than that which exists even in the laws of slavery, suggest that a full understanding of Cover's conception of nomos and narrative might require a close look at his conceptual analogue. A deeper appreciation for Cover's ideas could depend on an analysis of the biblical principles of succession, as well as a broader analysis of the place of nomos and narrative in Jewish thought.

\section{B. Cover's Analysis of Biblical Narrative}

The passages Cover cites read as follows:

If a man has two wives, one beloved and the other hated, and they have born him sons, both the beloved one and the hated one; and the first-born son is that of the hated one. On the day that he wills to his sons that which he possesses, he may not grant the son of the beloved wife the birthright

\footnotetext{
${ }^{46}$ See id. at 19-25.

${ }^{47} I d$. at 21 .

${ }^{48} I d$. at 35 .

${ }^{49} I d$.
} 
in place of the first-born, the son of the hated wife; but he must recognize the son of the hated wife as the first-born, by giving him a double portion of all that he possesses. Because he is the first of his manhood; the birthright is legally his. ${ }^{50}$

Cover considers the legal meaning and significance of the biblical principle of succession in the context of the nomos inhabited by "ancient Israel." 51 Cover first imagines a social setting bound by a law identical to the biblical precept, but one in which the precept is "simply stated, routinely obeyed, and subject only to the ordinary tensions of human psychology and ingenuity." 52 Cover contrasts this relatively simplified model against the social environment of the Bible, one filled with narratives creating a complex nomos within which the laws of succession had to be understood and applied..$^{53}$

Focusing on narratives found in the book of Genesis, Cover observes a recurring theme in which, contrary to the precept commanded in Deuteronomy, the eldest son was denied the right of primogeniture or a corresponding birthright, which instead was granted to his younger and more deserving sibling. ${ }^{54}$ This theme is initiated in the very first family, with the rejection of Cain's sacrifice, his exile, and his younger brother Seth's emergence as the ancestor of Noah, and, thus, of all human beings. ${ }^{55}$ The theme continues in Noah's family, as Shem receives a blessing greater than that of his older brother Yefeth, and becomes the progenitor of Abraham and Israel.$^{56}$ Perhaps the most dramatic example of the phenomenon Cover identifies, and the one most significant to the communal narrative of ancient Israel, involves the patriarchs. The lineage of the patriarchs consistently travels through a younger son, transmitted from Abraham to Isaac and finally to Jacob, who in turn endows Joseph with the birthright in place of Reuben, the eldest. ${ }^{57}$ In Cover's words, "all of the stories of the patriarchs revolve around the overturning of the 'normal' order of succession-a pillar of the legal civilization that is formally enunciated in the code portions of Deuteronomy itself." 58

${ }^{50}$ Deuteronomy 21:15-17.

${ }^{51}$ Cover, Nomos and Narrative, supra note 1, at 19.

${ }^{52} I d$. at 19.

${ }^{53}$ See id. at 19-21.

${ }^{54}$ See id. at $20-21$.

${ }^{\text {ss }}$ See Genesis 4:1-26; 5:9-29.

${ }^{56}$ See id. at 9:26-27; 10:10-26.

${ }^{57}$ See id. at $17: 19-21 ; 28: 1-4$.

${ }^{58}$ Cover, Nomos and Narrative, supra note 1, at 21 (citing M. WEINFELD, DEUTERONOMY AND THE DEUTERONOMIC SCHOOL 188 (1972)). 
Indeed, the narratives in Genesis are striking in their incongruence with the legal rules of succession delineated in Deuteronomy, providing a phenomenon ripe for discussion and discovery. Yet, for the legal theorist interested in construing the place of the biblical rules within the biblical nomos, Cover's conclusion that the narratives "can never be wholly squared ... with the formal rule"59 raises some questions.

Cover rejects the approaches by "later rabbis" to "reconcile the stories to the rule by creating exceptions or by positing circumstances that would remove the case from the rule. ${ }^{160}$ While acknowledging the efficacy of these approaches for "the later legist whose concern is a consistent body of precepts," Cover finds them less helpful in his own project, because "[1]ife in the normative world of the Bible ... required a well-honed sense of where the rule would end and why." 61

However, a reading of the biblical text on its face suggests that the grounds for Cover's objection are themselves somewhat problematic. The stories in Genesis depict the lives of the earliest human beings and the patriarchs, who are described as living in a time long preceding the institution of the legal precepts set forth in Deuteronomy. In fact, in light of the heavily legalistic society prescribed in the other books of the Torah, the world in which the patriarchs lived appears strangely bereft of a systematic nomos. While perhaps every society inhabits a certain nomos, and, to be sure, social norms are evidenced in the book of Genesis and the early sections of the book of Exodus, it is not until the Revelation at Sinai that a more express nomos is established.

Thus, it would seem that Sinai, where the Nation of Israel received the Law, provided the "well-honed" point of demarcation that Cover seeks for those living in the normative world of the Bible. ${ }^{62}$ It is possible that, to those living at the time that the Law was given, the rule of succession added a new shade of complexity to the stories in Genesis, which had been an integral part of the national narrative. Nevertheless, there was no need to "create exceptions" to "reconcile" the rule with the stories; the stories occurred in the context of a different normative world, that which existed before the Revelation provided the Nation a new nomos, one that included a rule of succession. ${ }^{63}$

${ }^{59} I d$.

${ }^{60} I d$. at $21-22$.

${ }^{61} I d$.

${ }^{62} I d$. at 22.

${ }^{63}$ In his Code of Law, based on biblical and talmudic sources, Maimonides succinctly portrays the development of the Law from the time of Adam and Eve until the Revelation at Sinai. According to Maimonides, Adam and Eve were given six fundamental commandments, while a seventh was commanded to Noah, completing the seven Noahide laws. A number of 
Ironically, it is the more complex hermeneutics of some of the "later rabbis" that actually may provide support for Cover's depiction of a normative world in which the stories in Genesis contradict legal precepts. Although the rule of succession is not delineated until Deuteronomy, some medieval biblical commentators identified allusions to the rule in the patriarchal stories. In particular, Jacob's statement to Joseph that "I have given you one portion above your brothers" ${ }^{\prime 64}$ is seen as endowing Joseph with the right of primogeniture in place of the eldest son, Reuben. As a result, Joseph's descendants received two portions in the Land of Israel, while the other tribes each received a single portion. ${ }^{65}$

An irony inherent in these hermeneutics—one acknowledged by the commentators-is that the narrative of Jacob and Joseph, which demonstrates the existence of the rule of succession prior to the Revelation, stands as a challenge to the rule. Indeed, Cover cites the story of Joseph, among the many narratives in Genesis, as a prime example of such a challenge.$^{66}$ Like Cover, the medieval commentators work to understand the narrative as it relates to this rule. While their primary goal may have been to offer a solution for a specific exegetical question, these scholars provide a broader method for explaining the place of the narrative of Jacob and Joseph within the biblical nomos. In fact, a close look at these scholars' methods may help illuminate more generally the relationship between nomos and narrative, in a manner that can be applied beyond the Bible to other normative worlds.

Cover writes of the effort to "creat[e] exceptions or ... posit[] circumstances that would remove the case from the rule." Although Cover finds this approach "tempting" becauge it results in "a consistent body of precepts,"

commandments were then given to the patriarchs and the enslaved Nation of Israel in Egypt. The vast majority of the 613 commandments were presented to Moses and the Nation of Israel at Sinai. MAIMONIDES, MISHNE TORAH [hereinafter MAIMONIDES, CODE OF LAW], Laws of Kings 9:1.

For discussion of the status of the majority of the commandments prior to the Revelation at Sinai, see JUDAH ROSANES, PARASHAT DERAKHIM; 1 NACHMANIDES, COMMENTARY ON THE TORAH 149-51 (Chaim Chavel ed., 1960) (commenting on Genesis 26:3).

${ }^{64}$ Genesis 48:22.

${ }^{65}$ See 1 NACHMANIDES, supra note 63, at 264 (commenting on Genesis 48:22); ABRAVANEL, COMMENTARY ON THE TORAH (commenting on Deuteronomy 21:15).

${ }^{66}$ See Cover, Nomos and Narrative, supra note 1, at 20,22. It is interesting that Cover emphasizes the events through which Joseph "is favored by his father, dreams of his own primacy, provokes retaliation, and comes to rule over his brothers, in an improbable political ascendancy in another land." Id. at 20 (citing Genesis 37:1-47:12). Although these events may be seen as somewhat incongruous with the rule of succession, they do not present the same legal challenge to the rule as that inherent in Jacob's granting Joseph a double portion, an episode that Cover does not discuss or cite.

${ }^{67} I d$. at 22. 
he attributes it to "later rabbis" and legists, and therefore rejects" it as unhelpful in understanding the attitudes of those living in the normative world of the Bible. ${ }^{68}$ Indeed, the Talmud offers a number of exceptions to the rule of succession, ${ }^{69}$ at least one of which provides an explanation for Jacob's actions. The Talmud acknowledges a modification of the rule of succession, finding that the father is precluded from favoring a younger son only if he does so as a result of his dislike for the mother of the eldest son. The father does not violate the rule, however, if he deprives the eldest son of the birthright as a result of the son's own wrongdoing. ${ }^{70}$ Some medieval biblical commentators understand Jacob's actions as an application of the talmudic principle, depriving Reuben of the birthright as a result of his wrongdoing. ${ }^{71}$

It does not appear accurate, however, to view either the talmudic hermeneutics or the commentators' understanding of Jacob's actions as an attempt by "later rabbis" to develop a legal system, consistent with the story of Joseph, that would have been unfamiliar to those living in biblical times. The Talmud's derivation of exceptions to and modifications of the rule of succession as stated in the Bible is not dependent on the story of Jacob and Joseph. It is the medieval commentators, not the Talmud, who applied the talmudic principles in order to understand Jacob's actions. The Talmud here does not appear to aim to reconcile the biblical narrative with the rule. Rather, the responsibility and primary interest of the rabbis of the Talmud is to interpret the legal text. Like many legal texts, the verses comprising the rule of succession contain language that inherently lends itself to different interpretations and must be applied to circumstances beyond those described in the three verses. As evidenced by the episode of the daughters of Tzlaphchad in Numbers, ${ }^{72}$ legal interpretation of the rule of succession was just as important and necessary for those living in the normative world of the Bible as it was for the rabbis of the Talmud.

If the Talmud's derivation of the exceptions to the rule of succession would be meaningful to those living in the times of the Bible, then the

${ }^{68} I d$. at $21-22$.

${ }^{69}$ See BaBYlonian TALMUD, Bava Bathra 108a-139b; see also id. at 126b, 156a. But see Cover, Nomos and Narrative, supra note 1, at $20 \mathrm{n} .51$ (stating that "[t]he later, Davidic legal traditions of the Israelites did not recognize a right on the part of the patriarch to designate an 'eldest' son").

${ }^{70}$ See BABYLONIAN TALMUD, Bava Bathra 133b-134a. Generally, however, the Talmud discourages a father from denying the oldest son the birthright. See id.

${ }^{71}$ See SFORNO, COMMENTARY ON THE TORAH (commenting on Deuteronomy 21:16) (citing BABYLONIAN TALMUd, Bava Bathra 133b-134a; 1 Chronicles 5:1-2); ABRAVANEL, supra note 65; see also Genesis 35:22; 49:4.

${ }^{72}$ See Numbers 27:1-11 (modifying rule of succession); ABRAVANEL, supra note 65 (discussing episode in light of rule of succession). 
application of the exception to the story of Jacob and Joseph may not have particularly surprised those who inhabited the biblical nomos. In fact, the medieval commentators who offer this explanation for Jacob's actions rely on a later biblical passage that appears to explicitly support their analysis. The verses in Chronicles state:

And the sons of Reuben, the first-born of Israel-for he was the first-born; but because he defiled his father's couch, his birthright was given to the sons of Joseph the son of Israel. And he was not considered in the genealogy as first-born; because Judah prevailed among his brethren and from him came the prince; but the birthright was Joseph's. ${ }^{73}$

Thus, the Bible itself provides the reason for Jacob's actions; the medieval commentators merely synthesized the talmudic rule with the biblical explanation. ${ }^{74}$

The explanations of these commentators, then, place Jacob's actions within the range of normative practice incorporated, through standard legal interpretation, as part of the rule. It seems consistent with Cover's interest in redemptive constitutionalism that, in contrast to these commentators, he prefers an explanation of the narrative that "associate[s] the divine hand of destiny with the typology of reversal of this particular rule." ${ }^{175}$ Cover thus pictures perhaps a more complex biblical nomos, in which the "inhabitant[s] . . . understand, first, that the rule of succession can be overturned; second, that it takes a conviction of divine destiny to overturn it; and third, that divine destiny is likely to manifest itself precisely in overturning this specific rule." 76

To be sure, there are many biblical narratives which are seen by the Talmud and later commentaries to be expressions of divine destiny overturning a rule. Indeed, one of the commentators who explains Jacob's actions according to the talmudic principle adds that Jacob acted under divine command. ${ }^{77}$ Nevertheless, in light of Cover's appreciation for the role of narrative in creating a community's nomos, his rejection of plausible legalistic interpretations in favor of divinely mandated noncompliance appears to be

${ }^{73} 1$ Chronicles 5:1-2.

${ }^{74}$ Commenting on the manner in which the Bible presents the rule of succession, Cover writes that "[t]he very casuistic phrasing of this precept suggests an extremely problematic psychodynamic." Cover, Nomos and Narrative, supra note 1, at 20. Abravanel, however, suggests that the Bible's scenario is in fact intended as an allusion to the story of Jacob and Joseph, which was an exception to the rule. See ABRAVANEL, supra note 65.

${ }^{75}$ Cover, Nomos and Narrative, supra note 1, at 22.

${ }^{76} I d$.

${ }^{77}$ See ABRAVANEL, supra note 65. 
more than a rejection of a specific hermeneutic. Cover prefers to see the "biblical narratives" as "reveal[ing] and reinforc[ing] a great fault line in the normative topography of the Israelites." ${ }^{278}$ Cover depicts a narrative challenge to legal precepts, which serves as a model for his understanding of the role of narratives relating to the laws of slavery, ${ }^{79}$ as well as his view of the more general relationship between nomos and narrative.

Despite the complexities involved in analyzing the biblical rule of succession, Cover refers to the Bible as a "highly simplified case," calling it "a literary artifact of a civilization [that] ... no more captures the full range of contested possibilities of ancient Israel than any similarly small composite of our texts would capture the full range of our normative potential." 80 Additionally, Cover observes, unlike the Bible, American legal texts do not include "an official, privileged canon of narratives." describes a "diffuse and unprivileged character of narrative in a modern world,"82 which results, in the United States, in a "complex nomos"83 consisting of "manifold, equally dignified communal bases of legal meaning that constitute the array of commitments, realities, and visions extant at any given time." 84 Yet, it may be this "simplified" quality of the biblical canon that makes it a particularly effective means for understanding Cover's vision. ${ }^{85}$ Before investigating a complex dynamic, it is often helpful to analyze a more basic model to arrive at conclusions that can then be applied to the more complex case.

As Cover explains in his Introduction:

I elaborate the unfamiliar idea of a nomos by providing an extended illustration through the use of biblical texts. I have chosen this material because the Bible constitutes a conventionally circumscribed corpus of integrated prescriptive and narrative material that can serve as an artificially simplified model. The sections that follow then apply the model to the more complex problems of creating constitutional meaning-problems that we meet in our own world-but concentrate on the creation of such meaning outside the official courts. ${ }^{86}$

\footnotetext{
${ }^{78}$ Cover, Nomos and Narrative, supra note 1, at 22.

${ }^{79}$ See id. at 35.

${ }^{80} I d$. at 19.

${ }^{81}$ Id. at 4 n.3.

${ }^{82} I d$.

${ }^{83}$ Id.

${ }^{84}$ See id. at 66.

${ }^{85}$ See id. at 19.

${ }^{86} I d$. at 10.
} 
Indeed, it may be the integration of and corresponding interrelationship between precepts and narratives in the Bible that Cover sees as an illuminating "illustration of the ways in which precepts and narratives operate together to ground meaning. ${ }^{187}$ In discussing his reliance on the Bible for a discussion of "the problem of legal meaning," Cover describes the Bible as "conventionally bounded," due to a "canon establish[ing] both that all biblical narrative is relevant to normative meaning and that no other material is." he writes, the Bible "demonstrates the irrelevance of genre to the creation of legal meaning. The narratives in question are relevant to the meaning of the biblical nomos not because they are true, but because they are biblical. That is, they are within a convention of established materials for interpretation." 89 Building on his understanding of the simplified, bounded system of the Bible, Cover embarks upon an analysis of the "problems of 'meaning' within our own nomos," in which "materials are less well bounded" and "[t]here are no easy conventions for the creation of meaning." 90 While the absence of a canonized narrative in the modern nomos, ${ }^{91}$ replaced instead by communal

${ }^{87}$ Id. at 19.

${ }^{88} I d$. at $24-25$.

${ }^{89}$ Id.

${ }^{90} I d$. at 25 . Cover's ambitious aim is to investigate the creation of legal meaning, emphasizing the "jurisgenerative" capacity of "communities that affirm a legal meaning opposed to that of the state." Id. at 10,25. These creators of legal meaning include "insular communities [that] establish their own meanings for constitutional principles through their constant struggle to define and maintain the independence and authority of their nomos," as well as "groups dedicated to radical transformations of constitutional meaning as it affects the application of state power." Id. at 25 . Cover contrasts the function of these groups against the "jurispathic" nature of courts, which, in their official capacities, must choose between competing narratives, such as, in the case of Bob Jones University, those of "the redemptive constitutionalism of an excluded race" and "of insularity, the protection of association." Id. at 66.

Professor Winter has described the role of "the judge or other legal storyteller," in Cover's view, as

tell[ing] a story that will be both meaningful and compelling ... [to] make use of preexisting cultural knowledge in ways that will seem natural to those subject to the legal rule because already grounded in social experience and mediated by existing cultural models.... This view of lawmaking acknowledges that those who comprise the legal hierarchy do exercise substantial power in choosing legal rules or cultural norms; they may pick and choose from amongst a broad stock of practices those that will be institutionalized in legal rules.

Winter, supra note 4, at 2270.

${ }^{91}$ Some scholars have observed the presence of narrative in what is generally viewed as strictly legal material. See, e.g., David Ray Papke, Discharge As Denouement: Appreciating the Storytelling of Appellate Opinions, 40 J. LEGAL EDUC. 145, 145 (1990) (suggesting that "appellate opinion has an inherent tendency to tell stories"); Rock, supra note 8, at $1017 \mathrm{n} .15$ ("What, for me, is so striking about the Delaware [corporate law] cases is that storytelling is so prominent in the decisions and so unabashedly normative."); $c f$. Cover, Nomos and Narrative, 
and often competing narratives, lends complexity to Cover's analysis, in Cover's view, the difference between the biblical nomos and the more complex modern nomos is one of degree rather than of kind. Thus, conceding that "[i]n our own normative world, there is no obvious central text ... that exhaustively supplies both narrative and precept," Cover nevertheless follows his discussion of the biblical nomos with an effort to "understand the creation of legal meaning" in this more complex nomos..$^{92}$ Ultimately, both models are best understood through a similar method of examining the fundamental question of the relationship between nomos and narrative.

In fact, Cover's very conception of "nomos" and "narrative" appears influenced by, if not a direct application of, the parallel notions of "halacha" and "aggada" in Jewish legal thought. Acknowledging that the "idea of a nomos" is "unfamiliar," starting with the very first line of his article, which declares, "We inhabit a

supra note 1, at 9 ("The normative meaning that has inhered in the patterns of the past will be found in [among other sources] the history of ordinary legal doctrine at work in mundane affairs."). In Halachah and Aggadah, Hayim Nahman Bialik states,

[T] he Hebrew halacha is almost entirely free from abstractions; almost throughout it is descriptive and concrete.

"Two men take hold of a shawl"; "When the potter puts in his pots"; "When a man puts down his cask"- this is the invariable style of the Hebrew halacha. Almost from beginning to end it is a kaleidoscope of pictures, large and small, of actual Hebrew life over a period of a thousand years and more ....

When, for instance, a Jew reads the Tractate Zera'im [talmudic agricultural law], does it never happen that there comes to him from its pages a breath of life, a scent of the earth and the grass, so that of a sudden he forgets that he is sitting and studying .... and sees the common people-the "men of the earth"-at their work in field and garden and vineyard and threshing-floor, with the priest doing his round, and the poor and the needy gathering the stray ears, falling on them, or spreading a cloak over them to establish a claim, and fighting over the booty with their sickles; or the variegated field, with its wheat and rye-grass and asparagus, its fenugreek and purslane, and the vine trained on the fig-tree, and the ant-hills in the standing corn, and the wind stirring the vines, and the gatherer of wet leaves and the collector of dry twigs, and the grape-gatherer snipping off the cluster which, in its tangle of leaves, slips from his hand to the ground and breaks; or the basket of wheat with the one grain that exempts it from the tithe; or the stag bought with tithe-money; or the shepherds eating dog-biscuit; or the ripe pomegranate tied up with a reed; or the young pigeons on the baskets-and so forth and so forth?

And when he goes on to the Tractates $M o^{\prime} e d$ [holidays] and Nashim [family law], does he not see with his own eyes the family life of the Hebrews, complete in all the fullness of its detail? And then $N^{\prime}$ zikin [torts]-can he take up this Tractate without seeming to see the Hebrew street and market-place, frozen suddenly one day in the midst of their business and bustle?

HAYIM NAHMAN BIALIK, HALACHAH AND AGGADAH 22-24 (Leon Simon trans., 1994).

${ }^{92}$ Cover, Nomos and Narrative, supra note 1, at 25.

${ }^{93}$ Id. at 10. 
nomos-a normative universe. ${ }^{94}$ This normative world consists not only of legal precepts and institutions; an important component of the normative world is the narratives that "locate" and "give ... meaning" to the rules." Cover emphasizes that "[t]o inhabit a nomos is to know how to live in it." Living in a nomos provides "an integrated world of obligation and reality from which the rest of the world is perceived."

Similar to Cover's definition of a "nomos," the Hebrew term "halacha," though implying a legal order and often used to denote "Jewish religious law," suggests a broader range of ideas than those included in legal rules. A more literal translation of "halacha" would evoke a "path" of life; to inhabit the halacha is, by definition, to live in it. ${ }^{8}$ Thus, the halacha truly provides a "world-view" through which all of the world and life's experiences are perceived. ${ }^{100}$ Moreover, as a path of life, halacha incorporates those aspects of normative life that complement the legal precepts, the aggada. ${ }^{101}$ Like "narrative," the term "aggada" can take on various meanings. However, when

${ }^{94} I d$. at 4.

${ }^{95}$ Id.

${ }^{96} I d$. at 6.

${ }^{97} I d$. at 31 .

${ }^{98}$ Professor Jeffrey Roth has compared Cover's conception of law as a bridge with the concept of halacha. See Jeffrey I. Roth, Crossing the Bridge to Secular Law: Three Models of Incorporation, 12 CARDOZO L. REV. 753, 753 (1991).

Professor Roth cites Cover's depiction of law as "the way a group of people will attempt to get from here to there." Id. (citing Cover, The Folktales of Justice: Tales of Jurisdiction, supra note 3, at 181); see supra note 39 and accompanying text. Roth suggests that

[d]efining law as "a way" has an unmistakable Jewish resonance. The Hebrew word for Jewish law, halacha, is derived, according to some scholars, from the root halach, meaning "to walk" or "to go." Jewish law is thus a way or path, the road Israel follows to transform itself from an ordinary nation into a holy people and a nation of priests.

Id. at $753 \mathrm{n} .3$ (citations omitted).

${ }^{99}$ JOSEPH B. SOLOVEITCHIK, HALAKHIC MAN 94, 94 (Lawrence Kaplan trans., 1983).

${ }^{100}$ Rabbi Joseph Soloveitchik has written eloquently and extensively about the power of halacha to create a world view. For example:

According to the outlook of halacha, the service of God ... can be carried out only through the implementation, the actualization of its principles in the real world. The ideal of righteousness is the guiding light of this world-view.... The halacha is not hermetically enclosed within the confines of cult sanctuaries but penetrates into every nook and cranny of life. The marketplace, the street, the factory, the house, the meeting place, the banquet hall, all constitute the backdrop for religious life.

Id.

${ }^{101}$ Cf. Aaron Kirschenbaum, Modern Times, Ancient Laws-Can the Torah be Amended? Equity as a Source of Legal Development, 39 ST. LouIs U. L.J. 1219, 1219 (1995) ("Halacha refers to the entire gamut of human behavior ritual as well as ethical, religious as well as 'secular."'). 
used in contrast to and in conjunction with halacha, the term evokes some of the philosophical, emotional, religious, and social expressions that provide a context for and a deeper meaning to the legal precepts. ${ }^{102}$

Therefore, an attempt to better understand Cover's thoughts might benefit from a fuller understanding of the complex interrelationship of halacha and aggada in Jewish thought. Towards that end, Part III of this Article continues with an examination of the interplay between halacha and aggada as demonstrated in central Jewish religious texts that integrate the two concepts. ${ }^{103}$

\section{NOMOS AND NARRATIVE IN JEWISH LEGAL SOURCES}

\section{A. Halacha and Aggada in the Torah}

Though often translated as "narrative,"104 the term "aggada" is somewhat ambiguous in meaning, ${ }^{105}$ and open to a broad range of interpretations. ${ }^{106}$ Rejecting various narrow definitions offered by "modern scholars," 107 David Stern observed that aggada includes "a widely heterogeneous body of materials that range from extra-biblical legends and tales about the rabbis to

${ }^{102}$ Some of Cover's friends have noted the parallel between "nomos and narrative" and "halacha and aggada." For example, Rabbi Joseph Lukinsky, who knew Cover as a teenager and to whom Cover declared his "deepest debt" for "first open[ing] my eyes to the complexity of moral choice," see COVER, JUSTICE ACCUSED, supra note 40, at xi, has written, and stated on a number of occasions, that "nomos and narrative" is "a conscious translation of the conceptions of halacha and aggada." Lukinsky \& Abramson, supra note 4, at 11; cf. Wizner, supra note 4, at 1710 ("Bob was a committed Jew. He experienced fully the halacha and aggada, the nomos and narrative, the myth, law, and history, the ethical aspirations, of the Jewish people."); see also Tucker, supra note 4, at 21 ("'Nomos' and 'narrative' were, to some of us who read this article, changelings which had supplanted the more resonant terms 'halacha' and 'aggada."').

${ }^{103} \mathrm{Cf}$. Apt, supra note 8, passim (offering different approach to relationship between aggada, narrative, and law).

${ }^{104}$ See, e.g., 2 ENCYCLOPEDIA JUDAICA 354 (1972) (translating term aggada).

${ }^{105}$ As one scholar put it, "The term aggada ..., , literally 'that which is told,' tells us more about the manner of its transmission than about the content of what was transmitted. The rabbis themselves never define aggada . ..." David Stern, Aggadah, in CONTEMPORARY JEWISH RELigious THOUGHT 7 (Arthur A. Cohen \& Paul Mendes-Flohr eds., 1987).

${ }^{106}$ As Cover observes in discussing "Torah," "nomos," and "the Law," certain terms are "amenable to a range of meanings that serve both to enrich the term and to obscure analysis of it." Cover, Nomos and Narrative, supra note 1, at 11 n.31.

${ }^{107}$ Stern, supra note 105, at 7. These definitions included " "scientific mythology," " "a tale implied or derived from Scripture," and "speculation with edification in view." Id. (citations omitted). 
snippets of popular folklore and fully elaborated homilies." ${ }^{108}$ This definition acknowledges that the significance of aggada, like that of Cover's "narrative," owes less to its literary form than to its power to convey national, cultural, and societal attitudes.

Yet, even such a broad definition restricts the range of aggada to "the entire body of rabbinic tradition," 109 thereby excluding narrative portions of the Bible such as those analyzed by Cover. Notably, though, Stern's work is a technical and systematic attempt to explain the literal meaning of the term "aggada" in Jewish literature. Cover's analysis discusses the broader concept of narrative, and by association aggada, which includes not only rabbinic literature but portions of the Bible as well. ${ }^{110}$

Indeed, Cover's discussion of the relationship between the biblical rule of succession and the Genesis narratives illustrates the important role that biblical narratives play, together with biblical precepts, in creating a "normative universe." "111 Even a cursory reading of the Torah reveals a literary work consisting of a continuous amalgamation of both precept and narrative. In some parts of the Torah the demarcation between the two forms is apparent, while in other areas precept and narrative are intertwined to comprise a single unit. Regardless of these distinctions, however, the Torah, as a whole, constitutes a foundation for the nomos of ancient Israel, as the aggada complements the legal precepts to inject meaning into the actions commanded, on both national and individual levels. ${ }^{112}$

${ }^{108}$ Id.; cf. 2 ENCYCLOPEDIA JUDAICA, supra note 104, at 356 ("The aggada comprehends a great variety of forms and content. It includes narrative, legends, doctrines, admonitions, words of encouragement and comfort, and expressions of hope and future redemptions.").

${ }^{109}$ Stern, supra note 105, at 7; cf. 2 ENCYCLOPEDIA JUDAICA, supra note 104, at 354 (defining aggada as "that portion of rabbinic teaching which is not halacha," but "in common with the halacha is part of the literature of the Oral Law").

${ }^{110}$ See BIALIK, supra note 91 , at 25 . Specifically, Bialik comments,

The words halacha and aggada come from the Talmud, where they have each a fixed meaning; but from the point of view of their inner reality their meaning is capable of extension and enlargement to cover the whole range of related phenomena, whether earlier or later than the Talmud. They are two definite forms, two distinct styles that go together in life and literature. To each age its own Id. aggada; to each aggada its own halacha.

"Cover, Nomos and Narrative, supra note 1, at 4.

${ }^{112}$ Rabbi Gordon Tucker has equated Cover's notion of "sacred narratives" with the "fact that Torah gives us law deeply intertwined with aggada." Tucker, supra note 4, at 26 . Professor Bernard Jackson similarly observes that "[t]here is an integral relationship between law and narrative in the Bible." Bernard S. Jackson, The Literary Presentation of Multiculturalism in Early Biblical Law, 23 INT'L J. SEMIOTICS L. 181, 182 (1995) (analyzing this relationship in number of contexts). 
Still, it is actually the final four books of the Torah which contain nearly all of the precepts commanded to the Nation of Israel. Certainly, these books are not bereft of narrative, including such dramatic events as the Exodus from Egypt, the Revelation at Sinai, the travels and travails in the desert, and the death of Moses. Indeed, the significance and meaning of the legal precepts are colored by the pivotal events that accompany their presentation. The book of Genesis, in contrast, consists almost entirely of narratives. While these narratives may suggest a certain nomos, they do not form the complex and comprehensive narrative universe created by the other four books of the Torah. Cover's focus on the rule of succession is particularly insightful because he identifies an area in which legal precepts are implicated by the Genesis narrative. Unlike the rule of succession, however, most of the precepts contained in the last four books of the Torah are not as clearly linked with events depicted in Genesis. This apparent lack of explicitly legal material in Genesis has led a number of scholars to examine closely the connection between the Genesis narratives and the nomos created by the Torah as a whole. The different approaches of some of these scholars may illuminate more generally the relationship between nomos and narrative.

Rashi, one of the earliest and greatest of medieval Bible scholars, ${ }^{113}$ inaugurates his commentary by citing a rabbinic source which asks why the Torah begins with the Genesis narrative rather than with the section of Exodus ${ }^{114}$ which contains the first command to the Nation of Israel. ${ }^{115}$ Rashi's question, like much of his commentary, inspired further discussion by generations of scholars who succeeded him. Rabbi Judah Loew of Prague (Maharal), in his sixteenth-century supercommentary to Rashi, explained that Rashi's question reflects a fundamental observation about the nature of the book of Genesis and its place in the Torah. According to Maharal, Rashi looked to the purpose of the Torah, suggested by the very name "Torah," which is a derivation of the verb "to teach." Rashi's question thus rested on the premise that the Torah's primary, if not exclusive, function is to teach the Nation the proper path of life it should follow, which is presumably enumerated in the commandments and not depicted in narrative. ${ }^{116}$

Rashi's answer to this question not only lends a legal context to the creation narrative, but also, like the narrative of Jacob that Cover examined, helps illustrate the normative world inhabited by ancient Israel. Again citing the earlier rabbinic source, Rashi states that the creation narrative, establish-

${ }^{113}$ See Chaim Chavel, Introduction to RASH, COMMENTARY ON THE TORAH (Chaim Chavel ed., 1986).

${ }^{114}$ See Exodus 12:2.

${ }^{115}$ See RASH, supra note 113, at 1 (commenting on Genesis 1:1).

${ }^{116}$ See MAHARAL, GUR ARYEH (commenting on RASH, supra note 113). 
ing the Omnipotent God as Sovereign over the world, provides the legal and moral authority for His dispossessing those nations living in the Land of Israel and granting the Land to the Nation of Israel. ${ }^{117}$ While Rashi's answer may be understood on a number of levels, and has, like his question, evoked a number of responses by later scholars, on a basic level the answer provides a legal significance to a narrative that otherwise appears unconnected to legal precepts. Yet, this explanation may remain insufficient to some who, like Maharal, suggest that the narratives in the Torah should relate more directly to actual legal precepts. ${ }^{118}$

To those raising such objections to Rashi's analysis, the commentary of another medieval biblical and legal scholar, Nachmanides, may prove more satisfying. ${ }^{119}$ Though apparently relying on the same rabbinic source as Rashi, Nachmanides interprets the source differently. ${ }^{120}$ Like Rashi, Nachmanides understands the Genesis narrative as a legal foundation for God's granting the Land of Israel to the Nation of Israel. Nachmanides, however, views the narrative as an expression of the legal principle of reward and punishment. ${ }^{121}$

Various stories in the book of Genesis tell of individuals and nations whose moral behavior is judged by God. In particular, Nachmanides notes the parallel between Adam and Eve, who were placed in the paradise of Eden and subsequently expelled for their sin, and the nations who occupied the Land of Israel but were ultimately uprooted from the Land because of their sins. ${ }^{122}$ In the context of these narratives, the nomos of ancient Israel included a realization that inhabiting the Land of Israel was conditioned on moral behavior.

Moreover, later in the Torah a number of specific precepts are presented together with admonitions against engaging in conduct similar to that of the nations who would be expelled from the Land. A chapter in Leviticus

${ }^{117}$ See RASHI, supra note 113.

${ }^{118}$ See MAHARAL, supra note 116.

${ }^{119}$ See 1 NACHMANIDES, COMMENTARY ON THE TORAH, supra note 63. Maharal actually explains Rashi's answer in a manner that connects more directly to commandments. Maharal notes that the majority of the commandments in the Torah are either agricultural commandments or relate to the service in the Temple. Because all of these commandments can be observed only in the Land of Israel, the lesson Rashi learns from the Genesis narrative, explaining the legal basis for the Nation's inhabiting the Land of Israel, is intrinsically connected to the commandments. See MAHARAL, supra note 116.

${ }^{120}$ Nachmanides interprets the question of why the Torah did not begin with the commandments in Exodus somewhat differently from Rashi. Nachmanides refers to the esoteric nature of the biblical depiction of creation, which he says is not properly understood on its face and requires an explanation that is known only to select individuals. See 1 NACHMANIDES, supra note 63, at 9 (commenting on Genesis 1:1).

${ }^{121}$ See id. at 9-10 (commenting on Genesis 1:1).

${ }^{122}$ See id. at 10 (commenting on Genesis 1:1) (citing Leviticus 18:24-28). 
delineating prohibited sexual conduct is framed by references to the immoral practices of those in the Land of Israel. ${ }^{123}$ Nachmanides alludes to some of the closing verses of the chapter, which state in stark and explicit terms the legal principles of reward and punishment that are apparent in the Genesis narrative:

In all of these [practices] the nations that I send from before you have been defiled ... and the Land has spit out its inhabitants ... you shall not commit any of these abominations ... and the Land will not spit you out ... as it has spit out the nations that were before you. ${ }^{124}$

Therefore, the Genesis aggada complements the legal portions of the other books of the Bible, providing a societal narrative that contributes to a national nomos in which living in the Land of Israel is contingent on national morality. ${ }^{125}$

Yet, even in this view of the Genesis narrative, the connection to legal rules is still somewhat indirect. Although the narrative serves as a powerful means for conveying the legal meaning and importance of commandments delineated elsewhere, the narrative itself does not teach independent legal precepts. An additional approach, offered by a contemporary scholar, Rabbi Joseph Soloveitchik, pictures biblical narrative not merely as aggada that lends meaning to legal precepts, but as another source of law. According to this approach, while narrative may differ, in form, from commandments, it too has the power to mandate obligations.

Relying on a talmudic exposition of the Genesis narrative involving the conversations of Abraham's servant, Eliezer, ${ }^{126}$ Rabbi Soloveitchik concludes that "[e]ven the Scriptural narratives serve the purpose of determining everlasting law.... Our Torah does not contain even one superfluous word or phrase. Each letter alludes to basic principles of Torah law, each word to

${ }^{123}$ See Leviticus 18:3, 24-28.

${ }^{124}$ Id. at 18:24-28.

${ }^{125}$ Professor Ronald Garet has observed that "the ethics of the religion of Israel could never simply be equated with an ethics of divine command." Ronald R. Garet, Natural Law and Creation Stories, in NOMOS XXX: RELIGION, MORALITY AND THE LAW 218, 224 (J. Roland Pennock \& John W. Chapman eds., 1988). Instead, he writes, they are also based in "the complex moral messages" transmitted by the biblical narratives." Id.; cf. Aharon Lichtenstein, Does Jewish Tradition Recognize an Ethic Independent of Halakha?, in MODERN JEWISH ETHICS: THEORY AND PRACTICE 6299 (Marvin Fox ed., 1975) (stating that "[w]hat I reject emphatically is the position that, on the one hand, defines the function and scope of halacha in terms of the latitude implicit in current usage and yet identifies its content with the more restricted sense of the term").

${ }^{126}$ See SOLOVEITCHIK, supra note 99, at 100 (citing BEREISHITH RABBAH 60:11). 
'well-fastened,' authoritative, everlasting [legal precepts]." ${ }^{127}$ Thus, it is the task of the scholar to "discern[] in every divine pledge man's obligation to bring about its fulfillment, in every promise a specific norm, in every eschatological vision an everlasting commandment .... The conversations of the servants, the trials of the fathers, the fate of the tribes, all teach the sons Torah and commandments." 128

Applying this principle to the creation narrative, Rabbi Soloveitchik declares that

if the Torah spoke at length about the creation of the world and related to us the story of the making heaven and earth and all their host, it did so not in order to reveal cosmogonic secrets and metaphysical mysteries but rather in order to teach practical halacha. The Scriptural portion of the creation narrative is a legal portion, in which are to be found basic, everlasting halakhic principles, just like the portion of Kedoshim or Mishpatim. ${ }^{129}$

The legal precept that Rabbi Soloveitchik derives from the creation narrative is "that man is obliged to engage in creation." 130 In fact, according to Rabbi Soloveitchik, through the creation narrative "[m]an, the creature, is commanded to become a partner with the Creator in the renewal of the cosmos"131 as an expression of "[t]he peak of religious ethical perfection to which Judaism aspires." 132 While the human act of creation can take on many forms, ${ }^{133}$ Rabbi Soloveitchik emphasizes the spiritual element, summarized

${ }^{127} I d$. at 99-100; $c f$. Winter, supra note 4, at 2267-68 (stating that "[t]he entire Jewish tradition of ... interpretive storytelling, is a tradition of lawmaking" and observing that rabbinic sources interpret a Genesis story of Abraham as a source of the legal obligations of "visiting the sick" and "entertaining strangers").

${ }^{128}$ SOLOVEITCHIK, supra note 99, at 100.

${ }^{129}$ Id. at 100-01 (scriptural citations omitted). These references are to portions in Leviticus and Exodus filled with legal precepts.

Professor Garet has similarly written that an "aspect of the Biblical narratives that does not neatly fit into a simplistic picture of divine commandments is the cosmogonic aspect: the creation stories of Genesis, and their echo throughout the Hebrew Bible." Garet, supra note 125 , at 226. Garet concludes that, in place of express commands, "[t]he natural order that God has created is in many ways a source of moral insight and instruction. The book of Job, for example, draws ethical instruction from our created nature." Id.

${ }^{130}$ SOLOVEITCHIK, supra note 99 , at 101.

${ }^{131}$ Id. at 105.

${ }^{132}$ Id. at 101.

${ }^{133}$ In his lectures, Rabbi Soloveitchik provided a more expansive picture of the human role as creator:

The convertibility of faith principles into moral directives may be implicit in the Creation story of Genesis 1 . Why does the Torah devote an entire chapter to the story of creation when, actually, all that emerges is a story which is unclear, 
in his portrait of the individual who "creates an ideal world, renews ... and transforms himself into a man of God, dreams about the complete realization of the halacha in the very core of the world, and looks forward to the kingdom of God . . . appearing in the midst of concrete and empirical reality."134 Thus, the extensive account of creation not only teaches an important legal precept, but provides the framework for a fundamental

incomplete, enigmatic, half-told, and half-concealed? The mystery of creation is thereby magnified, rather than dispelled. Even the chronology of creation as indicated in the text cannot be taken literally, as Rashi and others have indicated....

Perhaps this elaborate emphasis in the Book of Genesis on God's creation was meant to be converted into a moral challenge to man, that as God created, so should man. The foundation of our morality is: "And you should walk in His ways," that we imitate God. Man, like God, is often faced with utter desolation and he does not know where to begin. He doubts his ability to say "let there be light." It seems that the world can never be illuminated, such is the prevailing gloom. Yet man is bidden by the principle of imitatio Dei to create, to be a partner in fashioning form out of chaos. Of course, man does not create ex nihilo, as did God, though at times it seems to man that his task is as formidable as if it were from absolute nothing.

Man must be creative in both the material and spiritual realms. There are diseases to conquer, rivers to control, miseries to extirpate .... There is also the mandate to be creative in the spiritual realm ... education ... . is creativity par excellence. A formless, undirected child is transformed into a refined Torah scholar. An undisciplined child, without any identity, is gradually changed into a spiritual personality.... This is the spiritual dimension of parenthood, even as the commandment to bear children is physical creation.

Thus Genesis 1 challenges man to create, to transform wilderness into productive life; thereby, an article of faith becomes a moral principle.

ABRAHAM R. BESDIN, REFLECTIONS OF THE RAV: LESSONS IN JEWISH THOUGHT 25-27 (1979) (adapted from Lectures of Rabbi Soloveitchik) (citations and Hebrew phrases omitted); see also HERSHEL SCHACHTER, NEFESH HARAV 63-69 (1994) (describing Rabbi Soloveitchik's views).

${ }^{134}$ SOLOVEITCHIK, supra note 99, at 137 . Rabbi Soloveitchik develops these ideas at length in Part Two of Halakhic Man. See id. at 97-137. Some of his statements provide poignant expressions of his ideas, for example, "When God created the world, He provided an opportunity for the work of His hands-man-to participate in His creation. The Creator, as it were, impaired reality in order that mortal man could repair its flaws and perfect it." Id. at 101. "The perfection of creation ... is expressed in the actualization of the ideal halacha in the real world." Id. at 107-08. "The most fundamental principle of all is that man must create himself." Id. at 109. "When a person creates himself, ceases to be a mere species man, and becomes a man of God, then he has fulfilled that commandment ...." Id. at 128. "[T] his whole process of development unfolds in an ethical-halakhic spirit. The intellect, the will, feeling, the whole process of self-creation, all proceed in an ethical direction." Id. at 137.

Cf. Garet, supra note 125, at 249 (finding, in summary by Leo Strauss of creation story in Genesis, "an imago dei argument for human nature as self-creation or self- transformability, coupled with an account of the normative or political consequences that flow from human nature so described .... Only humanity can be self-creating, and in that sense mirror God the creator"). 
narrative lending a profound meaning to the entire biblical nomos: "Just as the Almighty constantly refined and improved the realm of existence during the six days of creation, so must man complete that creation and transform the domain of chaos and void into a perfect and beautiful reality." 135 Thus, while Rashi, Maharal, Nachmanides, and Rabbi Soloveitchik offer different explanations for the role of the Genesis narrative in the context of the other four books of the Torah, they all emphasize the importance of understanding the relationship between the aggadic material in Genesis and the halachic material found in the rest of the Torah, both of which together form the broader biblical nomos.

\section{B. Halacha and Aggada in the Talmud}

Although the Written Torah serves as the fundamental source of Jewish law, it is supplemented by the Oral Torah-the traditions and interpretations that were transmitted orally from the times of Moses until they were ultimately compiled as the Talmud. ${ }^{136}$ In part as a result of the method of its transmission, the Talmud includes more than strictly legal material. Rabbi Adin Steinsaltz has described the Talmud as "a conglomerate of law, legend and philosophy, a blend of unique logic and shrewd pragmatism, of history and science, logic and humor," in short, "the repository of thousands of years of Jewish wisdom." ${ }^{137}$ Thus, the Talmud is more than a legal code; it constantly enriches discussions of legal precepts with narrative elements that contribute to the broader Jewish nomos. ${ }^{138}$ In fact, Rabbi Steinsaltz has

${ }^{135}$ SOLOVEITCHIK, supra note 99 , at 106.

${ }^{136}$ Many scholars have discussed the history, structure, and methodology of the Jewish legal system, including the relationship between the Written Torah and the Oral Torah. See IRVING A. BREITOWITZ, BETWEen CIVIL LAW AND RELIGIOUS LAW: THE PLIGHT OF THE AGUNAH IN AMERICAN SOCIETY 307-13 (1993); MENACHEM ELON, JEWISH LAW: HISTORY, SOURCES, PRINCIPLES 228-39, 281-399 (Bernard Auerbach \& Melvyn J. Sykes trans., 1994); DAVID M. FELDMAN, BIRTH CONTROL IN JEWISH LAW: MARTTAL RELATIONS, CONTRACEPTION AND ABORTION 3-18 (1968); AARON KIRSCHENBAUM, EQUITY IN JEWISH LAW: HALAKHIC PERSPECTIVES IN LAW: FORMALISM AND FLEXIBIITY IN JEWISH CIVIL LAW 289-304 (1991); Menachem Elon, The Legal System of Jewish Law, 17 N.Y.U. J. INT'L L. \& POL. 221 passim (1985); Samuel J. Levine, Jewish Legal Theory and American Constitutional Theory: Some Comparisons and Contrasts, 24 HASTINGS CONST. L.Q. 441, 444-51 (1997).

${ }^{137}$ ADIN STEINSALTZ, THE EsSENTIAL TALMUd 4 (Chaya Galai trans., 1976).

${ }^{138}$ See id. at 3. As Rabbi Steinsaltz has put it,

If the Bible is the cornerstone of Judaism, then the Talmud is the central pillar, soaring up from the foundations and supporting the entire spiritual and intellectual edifice. In many ways, the Talmud is the most important book in Jewish culture, the backbone of creativity and of national life. No other work has had a comparable influence on the theory and practice of Jewish life, shaping spiritual content and serving as a guide to conduct. 
estimated that one fourth of the material in the Talmud may be classified as aggada. ${ }^{139}$ Just as the Talmud offers a much broader exposition of legal concepts than that found in the text of the Torah, the aggada in the Talmud provides extensive narratives that help create the normative world in which the legal precepts function. ${ }^{140}$

One of the most well-known and compelling of talmudic narratives is the story of the Oven of Akhnai. ${ }^{141}$ In this story, the Talmud relates a dispute

Id.

${ }^{139}$ See id. at 251.

${ }^{140}$ For an eloquent and moving testimony to the complementary nature of the legal and aggadic material in the Talmud, see SHMUEL HA-LEVI EDELS (MAHARSHA), Introduction to CHIDUSHEI HALACHOTH. One of the great Jewish scholars of the sixteenth and seventeenth centuries, Maharsha composed separate running commentaries, corresponding respectively to the legal and aggadic portions of the Talmud.

When publishing his works, Maharsha expressed regret for not following the format of the Talmud, a single work that blends legal and aggadic material. Maharsha acknowledged that the law as a whole is comprised of both legal precepts and aggada, which he called "sisters." Moreover, he observed the numerous moral imperatives contained in aggada. Therefore, Maharsha implored the reader to view his works as a single unit, to be read as a running commentary following the order of the material as presented in the Talmud. See id. To facilitate his wishes, Maharsha's commentaries, printed in most editions of the Talmud, have been rearranged and synthesized to correspond to the order of the talmudic material analyzed.

${ }^{141}$ Professor Suzanne Stone has referred to this narrative as "possibly the most frequently cited talmudic passage in modern literature," and "one of a handful of legal narratives that has captured the imagination of philosophers, psychologists, and literary critics, as well as legal scholars." Stone, supra note 4 , at 855,841 .

Cover was one of the legal scholars who cited this passage, writing that "[ $\mathrm{t}] \mathrm{he}$ issues raised by this midrash are connected to the theoretical, philosophical, and theological disputes that raged in Judaism for hundreds of years concerning the relative authority of law and prophecy." Cover, Nomos and Narrative, supra note 1, at 23 n.66 (citations omitted).

Another legal scholar, Professor Garet, makes a different observation, regarding what he calls "stories of deliverance, covenant, and law-creation." Garet, supra note 125, at 225. Garet asserts that

[t]he adjudicative function of such stories presupposes their authority to expound the law. The story of R. Eliezer mobilizes support for that supposition. Certain texts, the story suggests, have standing to shape or govern the understanding of the law. The Heavenly Voice, by contrast, lacks such standing. The authority of the canonical texts is traceable to the divine commands that the texts mediate; yet the Id. texts enjoy an autonomy....

Some contemporary American legal scholars have applied the lessons of the story of the Oven of Akhnai to American legal theory. See David R. Dow, Constitutional Midrash: The Rabbis' Solution to Professor Bickel's Problem, 29 Hous. L. REV. 543, 569-71 (1992); Daniel J.H. Greenwood, Akhnai, 1997 UTAH L. REV. 309, 327; Joshua Gutoff, The Necessary Outlaw: The Catastrophic Excommunication and Paradoxical Rehabilitation of Rabbi Eliezer ben Hyrcanus, 11 J.L. \& RELIGION 733, 736 (1995); Stone, supra note 4, at 840-47, 855-65 and accompanying footnotes. 
between Rabbi Eliezer and the majority of Sages relating to the ritual purity of a particular kind of oven. ${ }^{142}$ In order to demonstrate that his view was correct, Rabbi Eliezer summoned a number of miraculous events, culminating in a Heavenly Voice declaring that the law should follow Rabbi Eliezer's opinion. ${ }^{143}$ The Sages responded by noting that the law is "not in Heaven,"144 but instead, subsequent to the Revelation at Sinai, was placed in the province of humans. Therefore, the law was interpreted in accordance with the view of the majority of Sages and against the view of Rabbi Eliezer. ${ }^{145}$

On a concrete level, the narrative is important to the Jewish legal system because it resolves a specific legal issue that was subject to debate among decisionmakers. However, for centuries scholars have found that, on a broader level, the narrative illuminates many aspects of the normative world of the Talmud. ${ }^{146}$ Specifically, the narrative dramatically depicts and endorses a process of decision making that is fundamental and central to the world view of those inhabiting the Jewish nomos.

In analyzing the issue of legal authority in Jewish law, the medieval scholar Rabbenu Nissim Gerondi (Ran) relies heavily on the story of the Oven of Akhnai. Ran explains that, as a result of the various miraculous events, the majority of Sages recognized that Rabbi Eliezer's analysis was, in fact, "closer to the truth" than was their own. ${ }^{147}$ The Sages understood that the miracles were indeed a Divine validation of Rabbi Eliezer's view. ${ }^{148}$ Nevertheless, the Sages followed their own opinion, based on the principle that the duty and authority to interpret the law was given to humans, and thus the law is determined according to human, rather than Divine, logic. ${ }^{149}$

${ }^{142}$ See BABylonian TaLmUd, Bava Metzia 59b.

${ }^{143}$ See id.

${ }^{144} I d$. (analyzing Deuteronomy 30:12).

${ }^{145}$ See id. (analyzing Exodus 23:2).

${ }^{146}$ See Izhak Englard, Majority Decision v. Individual Truth: The Interpretations of the "Oven of Achnai" Aggada, 15 TRADITION 137 (1975) (compiling and discussing different interpretations of this narrative by scholars of Jewish law).

${ }^{147}$ RAN, DERASHOT 44, 112 (Leon A. Feldman ed., 1973).

${ }^{148}$ See id. at 45.

${ }^{149} \mathrm{See}$ id. Other scholars and legal authorities have relied on this narrative similarly to illustrate the power and accompanying responsibility of those who decide the law. See MOSHE FEINSTEIN, Introduction to IGROTH MOSHE (1959); ARYEH LEB HELLER, Introduction to KETZOTH HA-CHOSHEN.

Although the Sages rejected the view of Rabbi Eliezer, pursuant to the Torah's dictum establishing majority rule, Rabbi Eliezer's reasoning clearly represented a viable legal interpretation, indeed one more consistent with Divine logic. The Sages, however, followed an alternative interpretation, one they found more consistent with human logic. Thus, as I have developed elsewhere at greater length, the narrative exemplifies the principle that there can exist in legal reasoning more than one viable interpretation. See Levine, supra note 136, at 471-75; see also EloN, supra note 136, at 240-72 (discussing multiplicity of Jewish law 
According to Ran, because this principle of human legal authority is so fundamental to the Jewish legal system, it finds its fullest expression in the very first legal precept commanded to the Nation of Israel as a community. In the opening of the twelfth chapter of Exodus, before commanding the Nation to defy its Egyptian enslavers and conduct the original Passover ceremony, God directs Moses and Aaron to relate to the Nation that " $[t]$ his month shall be for you the beginning of the months; it shall be the first month of the year for you." 150 The oral tradition, documented in the Talmud, interprets this verse as a command to the High Court to sanctify the start of each month of the lunar calendar, based on lunar observation.

The talmudic exegesis of the verse focuses on the phraseology of the command, which tells the Nation, represented by the High Court, that "this month shall be for you." 151 This language is understood to emphasize that the establishment of the annual and monthly calendar is assigned to the Court, rather than being dictated by Divine decree. ${ }^{152}$ The extent of the Court's authority in this matter is unique in that it validates even a declaration of a new month that is later found to be have been issued in error. ${ }^{153}$ Thus, the very first legal precept presented to the Nation carried a powerful message about the function of legal authority within the broad communal nomos.

Indeed, in light of the form and substance of both the Torah and the Talmud, it is perhaps not surprising that aggada occupies a central place in these works. Though filled with legal precepts, the Torah and the Talmud are also designed to document and demonstrate the broader historical and social

interpretations); Michael Rosensweig, Eilu ve'Eilu Divrei Elokim Hayyim: Halakhic Pluralism and Theories of Controversy, in RABBINIC AUTHORITY AND PERSONAL AUTONOMY 93, 93-122 (Moshe Sokol ed., 1992) (exploring importance of controversy and pluralism in Jewish law).

In fact, the Talmud relates that, in the absence of an authoritative ruling by the High Court on a particular matter, individual communities, such as that of Rabbi Eliezer, followed their own minority interpretations. See ElCHANAN WASSERMAN, Kuntrus Divre Soferim, in KOBETZ SHIURIM 112 (Eliezer Wasserman ed., 4th ed. 1989). The Talmud's acceptance of both a theoretical and practical application of an individual community's minority interpretation evokes Cover's description of "a multiplicity of coherent systems," "interpretive efforts or traditions, each of which is independently defensible, or even 'right," and "the nomic integrity of each of the communities that have generated principles and precepts." Cover, Nomos and Narrative, supra note 1, at $28,17 \mathrm{n} .45,42$; see Levine, supra note 136 , at $472 \mathrm{n} .168,474-75$ nn.177-78.

${ }^{150}$ Exodus 12:2.

${ }^{151}$ BABYLONIAN TALMUd, Rosh Hashana 25a.

${ }^{152}$ See id. The communal recognition of the authority and responsibility of the Court in setting the monthly calendar, and thereby establishing the dates of the holidays, finds expression in the festival liturgy. See id. Beitza 17a.

${ }^{153}$ See id. Rosh Hashana 25a; cf. Owen M. Fiss, Objectivity and Interpretation, 34 STAN. L. REV. 739, 755, 758 (1982) (observing that "[j]udicial interpretations are binding, whether or not they are correct," and that "[a]n interpretation is binding even if [it is] mistaken"). 
condition of the Jewish nation at important stages of the law's development. A more striking demonstration of the importance of aggada to the meaning and understanding of Jewish legal precepts may be found in a more strictly legal work, the Code of Maimonides.

\section{Halacha and Aggada in Maimonides' Code of Law}

One of the greatest of medieval Jewish scholars, Maimonides produced a number of works that had a nearly unparalleled influence on both Jewish law and Jewish philosophy. ${ }^{154}$ In his magnum opus, Mishne Torah, often translated as a "Code of Law," Maimonides codified the entire corpus of legal precepts found in the Talmud. His compilation was so comprehensive that Maimonides declared in his Introduction that a person who read only the Written Law-the Bible-and the Mishne Torah could be familiar with all of Jewish law, without having to refer to the Talmud or any other works of the Oral Law. ${ }^{155}$ Like most codes in American law, however, and unlike the Talmud, the Mishne Torah does not always present a full explanation of the derivation and application of the legal precepts encompassed. ${ }^{156}$ Instead, the

${ }^{154}$ See ISADORE TWERSKY, INTRODUCTION TO THE CODE OF MAIMONIDES (MISHNEH TORAH) 1 (1980). Twersky observed that

[Maimonides'] reputation needs no inflation or exaggeration, for his stature is nearly sui generis and his commanding influence has been almost universally recognized. ... He wrote epoch-making works in the central areas of halacha and religious philosophy - an achievement that is unquestionably, almost overpoweringly, characterized by monumentality, using the term very literally. His works, representing an unprecedented conjunction of halachic authority and philosophic prestige, were extensively studied, meticulously annotated, frequently translated, and intensively interpreted. Their influence, direct as well as indirect, reflected Id. through many works in various genres by a host of authors, was global.

${ }^{155}$ MAIMONIDES, Introduction to CODE OF LAW, supra note 63.

${ }^{156}$ See TWERSKY, supra note 154, at 97 . Twersky writes, The codificatory form of Maimonides' work was central to his purpose. He aimed to produce ... a truly all-inclusive code[], a . . collection[] through which all halachic material would be sifted, pruned of associative discussion, digression, and indeterminate debate, and recast in a purified or rarefied form of uniform and normative conclusions and practical directives. This literary goal was frequently and unequivocally underscored by Maimonides, presenting the massive material in crisp and concise form, unobstructed and unencumbered.

Id. (footnote omitted). Indeed, some scholars criticized Maimonides for his failure to provide the sources and derivations of his legal conclusions. See RA'AVAD, Commentary to MAIMONIDES, CODE OF LAW, supra note 63; TWERSKY, supra note 154, at 102-05, 107-08. Professor Twersky documents a number of "exceptions to the austere codificatory form" of the Code, and reconciles these phenomena with Maimonides' stated goal. Id. at 108-75. 
Code of Maimonides consists chiefly of legal conclusions, as applied to specific fact patterns.

Nevertheless, at a number of points in this legal code, Maimonides included aggadic material that lends an added dimension of meaning and significance to the corresponding precepts. ${ }^{157}$ In one of the most powerful uses of aggada in the Mishne Torah, Maimonides relies on the centrality of the concept of imitatio Dei in Jewish thought to impress upon the reader the importance of helping the poor and underprivileged. ${ }^{158}$

In the final chapter of the section of the Mishne Torah dealing with estates, Maimonides discusses the obligations of those who are appointed legal guardians for orphans. After discussing the technical legal issues involved, Maimonides concludes with a prescription that "a guardian for orphans must be particularly careful in apportioning their property, for their Father is He Who rides in the Highest Heaven, as it is written, 'extol Him Who rides in the Highest Heaven, etc., Father of the orphans." "159

As one scholar observed, Maimonides carefully chose these references to God, taken from the Psalms, as a literary allusion to a passage in the Talmud. ${ }^{160}$ The Talmud states that "in every place that the grandness of God is found [in the Bible], so too is His humility found."161 As one of the prooftexts for this statement, the Talmud quotes the verses from Psalms which refer to God as both "Him Who rides in the Highest Heaven" and "Father of orphans." 162 By quoting these verses, then, Maimonides sends the strong message of an obligation, incumbent not only upon the guardians of orphans but on all those who wish to follow the Divine path, to care for those who are

${ }^{157}$ See generally Jeruchem Leiner, Halacha and Aggada at the Conclusion of the Books in the Mishneh Torah, 7 TALPIOTH 214 (1957) (noting and analyzing this phenomenon in Mishne Torah). Twersky also notes,

Aggada was a treasure trove which could be diligently searched and then creatively used to reinforce or refine a halachic formulation, to sustain a philological connection or conjecture, to exemplify an ethical trait, or to bolster a philosophic position. Maimonides, who had a sustained and life-long interest in Midrash, its hermeneutic problematics as well as its ideational potential, freely and effectively utilized nonhalachic materials throughout the Mishneh Torah. Aggada and halacha had a synchronic relationship; the tendency to separate completely these two cognate areas, which often merged, should not obscure the literary-conceptual reality of Maimonides' work, or indeed of his age as a whole.

TWERSKY, supra note 154, at 150.

${ }^{158}$ See SCHACHTER, supra note 133, at 59-71 (discussing centrality of imitatio Dei in Jewish thought).

${ }^{159}$ MAIMONIDES, CODE OF LAW, supra note 63, at Laws of Estates 11:12 (quoting Psalms 68:5-6).

${ }^{160}$ See Leiner, supra note 157, at 221-22; TWERSKY, supra note 154, at 134-35 n.123.

${ }^{161}$ BABYLONIAN TALMUD, Megilla $31 \mathrm{a}$.

${ }^{162}$ Psalms 68:5-6. 
in need. In fact, the quotation closes not only the section of the Mishne Torah relating to estates, but also a larger segment of the Code of Law, that includes many of the laws of commercial transactions and litigation. Thus, Maimonides uses aggada to remind those who are successful in business that their success should not lead them to believe that they are above helping those who are less fortunate than they are, as even God, as it were, couples His Own exalted nature with dedication to the downtrodden.

Maimonides based his Code of Law on the teachings of the Talmud, the authoritative source of law for the Jewish nation. Yet, Maimonides recognized that a Code of Law that contained only legal precepts could not fully serve the role he envisioned for the Mishne Torah, a work that would not merely state the law, but would, in connection with the Bible, demonstrate the function of legal precepts within the broader national nomos. ${ }^{163}$ In order to present a more complete picture of the halacha, Maimonides included segments of aggada which would resonate in the communal consciousness to complement the law and illustrate its meaning in the nation's societal universe. ${ }^{164}$

${ }^{163}$ See TWERSKY, supra note 154, at 166 ("A code ... in Maimonides' conception, should teach and expound while it directs, combining prescriptions with their rationales. Fixed laws ... should be studied and understood, not just obeyed .... There was no antipathy between brevity and completeness, systematic summation and thorough understanding, norm and explanation."). Twersky also notes,

[Maimonides] aspired to produce a law code which instructs as well as commands, thereby providing an effective instrument of education and edification, for law itself is an educative force leading to ethical and intellectual perfection. Law must, therefore, be understood and appreciated as well as obeyed and implemented. ... His Code, in short, would reflect his organic-philosophical conception of law.

Id. at 372.

${ }^{164}$ See id. at 371-72. Twersky writes,

[T] he Mishneh Torah itself provides a full and almost polychromatic reflection of [Maimonides'] unified preoccupation with philosophy and law, or the philosophicspiritualistic perception of law. The Mishneh Torah, anything but a cut and dried, rigorously functional code, pays attention ... to physics, metaphysics, psychology, dietetics, astronomy, Messianism, and the hereafter. It contains many philosophical comments, theological principles and rationalistic directives, comments on the history of religion and prophecy, science and medicine, and a full ethical system. It also has frequent ethical digressions and interpolations, for . . . Maimonides' systematization of the halacha included a good measure of ethicization and rationalization. Ethical assumptions and commandments are spelled out and made explicit. Ideals concretized in a particular law are articulated. Reasons for enigmatic precepts are suggested. Philosophical principles which provide the underpinning of legal details are identified. The thread of intellectualization and spiritualization ... is thus especially discernible in the texture of the Mishneh Torah. . . Maimonides tried to bring about the unity of practice and concept, 


\section{ROBERT COVER AND HAYIM NAHMAN BIALIK: TWO SIDES OF A SINGLE SHIELD}

Robert Cover was among the first of American legal scholars to analyze the relationship between nomos and narrative, and the first to use these terms to describe his unique vision of the interaction between legal precepts and the larger societal forces and attitudes which give them meaning. In Jewish thought, from Rashi to Rabbi Soloveitchik, legal scholars and philosophers have recognized that a complete understanding of the law requires an. understanding of the aggada which contributes to and interacts with the halacha ${ }^{165}$ Yet, perhaps the writer whose work can best help illuminate Cover's ideas was known not as a legal scholar but as a modern literary figure, Hayim Nahman Bialik. Indeed, there are striking parallels between the thoughts of Bialik, a writer of literature with a great respect for the law, and Cover, a legal scholar who saw literature as a means to gain a deeper understanding of human conduct and how such conduct relates to law. It may be fitting, then, that a study of Cover's ideas and their parallels in Jewish legal thought should include a comparison between Cover's writings and those of Bialik.

The conceptual similarities between the works of Cover and Bialik resonate in the very titles of their landmark essays. The title of Cover's article, "Nomos and Narrative," echoed the title of Bialik's essay, "Halachah and Aggadah," written nearly seventy years earlier. Bialik's fundamental

external observance and inner meaning, visible action and invisible experience.... This comprehensive Code takes within its purview, in other words, not only the laws but the theological stimuli and ethical underpinnings which suffuse the legal details with significance and spirituality, freshness and fullness. It was concerned ... with the religious consciousness and theological sensibility. The fixed law and the experiential component, action and reflection, were comId. bined. ... Polarity recedes and yields to complementarity.

${ }^{165}$ Martha Minow has written that Cover "inaugurated contemporary law school discussion of narrative and hermeneutics by reaching across time and space to the talmudic discussions by people who never knew law could be separated from narrative and hermeneutics." Martha Minow, Introduction: Robert Cover and Law, Judging, and Violence, in NARRATIVE, VIOLENCE, AND THE LAW: THE ESSAYS OF ROBERT COVER, supra note 2, at 11.

Rabbi Gordon Tucker has referred to Nomos and Narrative as a "landmark in jurisprudential writing," in which Cover "sought to effect a revolution in how people would see the legal universe." While "[ $t]$ he revolutionary character of this understanding was not lost on at least some of its readers," Tucker writes that "for others, 'Nomos' and 'Narrative' did not so much point to a revolution as bestir deep memories. 'Nomos' and 'Narrative' were, to some of us who read the article, changelings which had supplanted the more resonant terms 'halacha' and 'aggada." Tucker, supra note 4 , at 21 . Tucker also notes briefly the parallel between Cover's ideas and those of Bialik. See id. at 21-22. 
thesis is that "halacha and aggada are two things which are really one-two sides of a single shield."166 "Halacha is the crystallization, the highest quintessence of aggada, while aggada is the refinement of halacha."167 Central to Cover's writing is a similar acknowledgment that societal narrative is not alien to a nomos, but rather contributes to and is crystallized in the normative world, in which narrative refines and gives meaning to technical legal precepts. In Cover's language,

No set of legal institutions or prescriptions exists apart from the narratives that locate it and give it meaning. ... Once understood in the context of the narratives that give it meaning, law becomes not merely a system of rules to be observed, but a world in which we live.

In this normative world, law and narrative are inseparably related. ${ }^{168}$

Thus, in American constitutional law, the religious freedoms guaranteed by the First Amendment take on a special significance and meaning to those normative communities whose historical narrative includes being the victim of religious persecution. ${ }^{169}$ In Jewish law, the imperative to help those in need has added meaning when viewed in light of a communal narrative that values emulating God, Who is pictured as caring for the unfortunate. ${ }^{170}$

Indeed, the sum total of legal and social attitudes and phenomena comprises a communal normative universe. As Bialik describes it, "[t]he creations of halacha ... grow little by little, piece by piece, out of all the stream of human life and action, till in the end the fragments add up to a single total, and produce a single form." ${ }^{\text {"171 }}$ Ultimately, though, halacha requires an underlying commitment to God and His law:

${ }^{166}$ BIALIK, supra note 91 , at 9.

${ }^{167} 2$ ENCYCLOPEDIA JUDAICA, supra note 104, at 354 (translating BIALIK, supra note 91, at 9).

${ }^{168}$ Cover, Nomos and Narrative, supra note 1, at 4-5. Bialik's description of halacha and aggada as "two things which are really one," BIALIK, supra note 91, at 9, resonates in Cover's opening quotation from a poem by Wallace Stevens:

A. A violent order is disorder; and

B. A great disorder is an order. These

Two things are one.

Cover, Nomos and Narrative, supra note 1, at 4 (quoting WALLACE STEVENS, Connoisseur of Chaos, in THE COLLECTED POEMS OF WALLACE STEVENS 215 (1954)) (italics omitted).

David Stern has contrasted the "chaotic richness" of aggada against the more rigid and systematic nature of law. See Stern, supra note 105 , at 12 . Cover similarly writes of the "radically uncontrolled" nature of narrative, compared with the "social control" that exists over "[t]he precepts we call law." Cover, Nomos and Narrative, supra note 1, at 17.

${ }^{164}$ See supra text accompanying notes $20-28$.

${ }^{170}$ See supra Part III.C.

${ }^{171}$ BIALIK, supra note 91 , at 11 . 
Halacha ... has shaped and trained a whole nation, and every line that it has graven on the nation's soul ... has been inspired and guided by a supreme wisdom which sees the end in the beginning. Day by day, hour by hour, minute by minute, it is intent on its task of creating one form and one form only - the true likeness of God's creatures, the image of God in man. ${ }^{172}$

Cover similarly sees a nomos comprised of both legal precepts and the underlying historical communal values and commitments that give meaning to the laws. Thus,

a lexicon of normative action ... may be combined into meaningful patterns culled from the meaningful patterns of the past. The normative meaning that has inhered in the patterns of the past will be found in the history of ordinary legal doctrine at work in mundane affairs; in utopian and messianic yearnings, imaginary shapes given to a less resistant reality; in apologies for power and privilege and in the critiques that may be leveled at the justificatory enterprises of law. ${ }^{173}$

Ultimately, Cover finds that " $[t]$ he range of meaning that may be given to every norm" is defined "both by a legal text, which objectifies the demand, and by the multiplicity of implicit and explicit commitments that go with it." 174 It is "[t]he narratives that any particular group associates with the law [that] bespeak the range of the group's commitments."175

In accordance with its communal narrative and commitments, the group possesses a vision of its role and destiny in the world. It is the aggada, writes Bialik, through which the nation "deals with what ought to be and what might be . . . the desires, the pre-occupations, the ideal of the Jewish people."176 Cover paints a similar picture of the law as "a bridge linking a concept of reality to an imagined alternative-that is, as a connective between two states of affairs, both of which can be represented in their normative significance only through the devices of narrative."177 Echoing Bialik, Cover refers to narrative as integrating the "“is," the "cought,"” and the "w what might be." 178

Nevertheless, both Bialik and Cover emphasize that the relationship between nomos and narrative is premised on the abiding need for and

${ }^{172} I d$.

${ }^{173}$ Cover, Nomos and Narrative, supra note 1, at 9.

${ }^{174} I d$. at 46.

${ }^{175} I d$.

${ }^{176}$ BIALIK, supra note 91 , at 22.

${ }^{17 n}$ Cover, Nomos and Narrative, supra note 1 , at 9.

${ }^{178} I d$. at 10. 
authority of actual and concrete law. Like a nomos, "halacha, fed by the actual world, deals with what exists and is established; it shows us unmistakably, in small but clear vignettes, the actual, concrete life of the people." ${ }^{179}$ In fact, according to Bialik, "[t]he value of aggada is that it issues in halacha." Therefore, he warns, "aggada that does not bring halacha in its train is ineffective. Useless itself, it will end by incapacitating its actor for action." 180

Near the end of his essay, Bialik writes at length and poetically about the emptiness of an aggada that exists in the absence of law and a normative world:

If a man professes to have nothing but aggada, his aggada should be narrowly examined; you may suspect it of being no more than a pretty flower. Such a man wants to pluck the flowers, but cares nothing for the fruit. In the end not even the flowers will reward him; for without fruit there is no seed, and if there is no seed, where is the flower to come from?

The shafts of aggada are uncertain in their aim, and come with a swerve, as though shot from a loose bowstring; those of halacha fly straight and true, with the strength and directness imparted by a welldrawn bow . . . Where aggada has no aftermath of halacha in the national life, the nation will wander endlessly in the vague, and will be in danger of forgetting the straight and only way from will to action, from aspiration to achievement.

Halacha linked with aggada means assurance of health and a certificate of national maturity; but wherever you find aggada in isolation, be sure that the nation's power to act and instruments of action are weak and need medicine. ${ }^{181}$

Cover, whose admiration for narrative mirrors Bialik's admiration for aggada, issues similar warnings. Having developed the notion that a nomos consists, in part, of "alternity," Cover declares that

the concept of a nomos is not exhausted by its "alternity"; it is neither utopia nor pure vision. A nomos, as a world of law, entails the application of human will to an extant state of affairs as well as toward our vision of alternative futures. A nomos is a present world constituted by a system of tension between reality and vision.

${ }^{179}$ BIALIK, supra note 91 , at 22 ; see supra note 91.

${ }^{180}$ BIALIK, supra note 91 , at 22.

${ }^{181}$ Id. at 26; cf. Stern, supra note 105, at 11-12 ("The possibility of a new aggada freed from the fetters of the halacha, which some modern thinkers have invoked as the basis for a Judaism redivivus, is in fact unattractive: such an aggada would be groundless, soft, a kind of piety lacking the hard commitment and demand of law."). 
Our visions hold our reality up to us as unredeemed. By themselves the alternative worlds of our visions ... dictate no particular set of transformations or efforts at transformation. But law gives a vision depth of field, by placing one part of it in the highlight of insistent and immediate demand while casting another part in the shadow of the millennium. ... Law is a force ... through which our worlds exercise an influence upon one another, a force that affects the courses of these worlds through normative pace. And law is that which holds our reality apart from our visions and rescues us from the eschatology that is the collision in this material social world of the construction of our minds. ${ }^{182}$

Indeed, Cover's vision of nomos and narrative may best be summarized through Bialik's vision of halacha and aggada: "Halacha [is] a concrete and definite form of actual life, of a life which is not in the clouds, which does not depend on vague feeling and beautiful phrases alone, but has physical reality and physical beauty. Halacha in that sense, I assert, is but the inevitable continuation and sequel of aggada."183

\section{CONCLUSION}

Robert Cover's Nomos and Narrative appears to have been one of the catalysts for a growing body of interdisciplinary literature in the areas of legal narrative ${ }^{184}$ and the comparative study of Jewish law and American legal theory. ${ }^{185}$ Yet, the terms "interdisciplinary" or "comparative" do not capture adequately the vision that Cover incorporated into his works and, according to his friends, his life. ${ }^{186}$

${ }^{182}$ Cover, Nomos and Narrative, supra note 1, at 9-10. Cover similarly writes: If law reflects a tension between what is and what might be, law can be maintained only as long as the two are close enough to reveal a line of human endeavor that brings them into temporary or partial reconciliation. All utopian or eschatological movements that do not withdraw to insularity risk the failure of the conversion of vision into reality and, thus, the breaking of the tension. At that point, they may be Id. at 39.

movements, but they are no longer movements of the law.

Cover later explored the tension between legal and eschatological visions, in the context of the efforts by sixteenth-century legal scholars and mystics in Safed to renew semikha, the ancient form of rabbinic ordination. See Cover, Bringing the Messiah Through Law: A Case Study, supra note 3; Cover, The Folktales of Justice: Tales of Jurisdiction, supra note 3.

${ }^{183}$ BIALIK, supra note 91 , at 26.

${ }^{184}$ See supra note 8.

${ }^{185}$ See supra note 4; works cited in Levine, supra note 136, at 442-43 nn.3-7; works cited in Stone, supra note 4, passim.

${ }^{186}$ See supra note 4. 
Cover's depiction of the relationship between nomos and narrative transcends the notion of integrating two apparently distinct concepts, representing distinct intellectual disciplines, to arrive at a better understanding of each concept. Cover does not need to devise a method for connecting nomos and narrative, because he starts from the premise that they are already inherently and inextricably linked. ${ }^{187}$ His project, then, is to investigate their relationship and how they function in society.

Likewise, Cover does not merely compare Jewish law and American legal theory. Cover's incorporation of biblical narrative and, if only implicitly, the concepts of halacha and aggada, appropriately characterizes his intellectual approach. His work reflects a fundamental appreciation for the underlying relationship between different intellectual strands. As his friends and teachers, Rabbis Joseph Lukinsky and Robert Abramson, have observed,

[Cover's] mind and taste for argumentation were not first sharpened at the yeshivah on the whetstone of talmudic logic and then transferred to law in general. It was more profound; from youth he had come to see law as the embodiment of values and a way of thinking about and acting upon them, the medium in the American and Jewish legal traditions for making... justice tangible....

Bob's world was not so much inter-disciplinary as inclusive. For him the humanities, religion, and the law were not distinct, but interactive synergistic. Law was a humanistic attempt to create meaning in the ethical sphere and beyond. ${ }^{188}$

It is fitting that Cover's friend, Professor Stephen Wizner, spoke of a similarly integrated life, in which Cover "experienced fully the halacha and aggada, the nomos and narrative, the myth, law and history, the ethical aspirations, of the Jewish people,"189 and a life in which "[t]he confluence of religion, law, and politics, in ... Bob's last scholarly project, was a summation of his vision of law as a sacred art, a bridge from reality to a new world."190

${ }^{187}$ See Tucker, supra note 4, at 21 (explaining that Nomos and Narrative "went far beyond mere interdisciplinary daring. ... Cover sought to effect a revolution in how people would see the legal universe. Rules and the narratives in which they are embedded would henceforth have to be treated with parity, as equal partners in the creation of a normative universe").

${ }^{188}$ Lukinsky \& Abramson, supra note 4, at 11.

${ }^{189}$ Wizner, supra note 4 , at 1710.

${ }^{190}$ Id. at 1711 (referring to Cover, Bringing the Messiah Through Law: A Case Study, supra note 3); $c f$. Minow, supra note 165, at 11 ("[Cover] himself made a bridge. He connected the communal and the liberal, the religious and the secular, the moral and the legal. . . . Cover insisted that legal scholarship connect to the largest issues of spiritual and emotional meaning."). 